ECONOMÍA: TEORÍA Y PRÁCTICA • Nueva Época, número 44, enero-junio 2016,

pp. 9-50, http://www.izt.uam.mx/economiatyp/ojs

\title{
Money Laundering and Financial Risk Management in Latin America, with Special Reference to Mexico*
}

\section{Lavado de dinero y manejo de riesgos financieros en América Latina, con especial referencia a México}

\author{
Willy Zapata Sagastume, ${ }^{* *}$ Juan Carlos Moreno-Brid*** \\ and Stefanie Garry**
}

\begin{abstract}
This paper reviews the current status of the international fight against money laundering and the financing of terrorism, highlighting the importance of its prevention for economic and financial stability in Latin America and the Caribbean. It reviews Latin American and Caribbean countries' compliance with the Financial Action Task Force (FATF) $(40+9)$ Recommendations, and analyzes the region's performance with respect to their third round Mutual Evaluation Reports. The case study of Mexico provides specific insight into the country's reforms and policies to combat these financial sector operational risks.
\end{abstract}

Keywords: Money Laundering, Financing of Terrorism, Financial Sector Regulation, Compliance, Latin America and the Caribbean, Mexico. JEL classification: F42, G28, H26, K42.

\section{RESUMEN}

Este documento examina el estado actual de la lucha internacional contra el lavado de dinero y el financiamiento del terrorismo, con énfasis en la importancia de su prevención para la estabilidad económica y financiera en América Latina y el Caribe. Se revisa el cumplimiento de los países de la región de las recomendaciones del Grupo de Acción Financiera $(40+9)$ y se analiza el desempeño de la región respecto a su tercera ronda de Informes de Evaluación Mutua. El caso de México proporciona información específica sobre sus reformas y sus políticas para combatir estos riesgos operacionales del sector financiero.

Palabras clave: lavado de dinero, financiamiento del terrorismo, regulación del sector financiero, America Latina y el Caribe, México.

Clasificación JEL: F42, G28, H26, K42.

* Fecha de recepción: 01/12/2015. Fecha de aprobación: 08/04/2016. The views expressed in this document are those of the authors and do not necessarily reflect the views of the UN. A preliminary, non edited and much longer version appeared as a working paper of ECLAC-Mexico, "Prevention of Money Laundering and of the Financing of Terrorism to Ensure the Integrity of Financial Markets in Latin America and the Caribbean.” Estudios y Perspectivas - Sede Subregional de la CEPAL en México, November 2014.

** International Adviser in Finance and Banking. E mail: zapatawilly@gmail.com.

*** Facultad de Economía at Universidad Nacional Autónoma de México. E mail: juancarlos morenobrid@gmail.com.

**** Economic Comission for Latin America and the Caribbean. E mail: Stefanie.GARRY@cepal.org. 


\section{INTRODUCTION}

The paper reviews the current status of the struggle against money laundering and the financing of terrorism in Latin America and the Caribbean. For this purpose, it first examines the various agreements and resolutions concerning this issue at global and regional levels. It then provides a description of the money laundering process and the importance of its prevention for economic and financial stability, including a discussion of some effects in the real sector.

Next, a discussion of the trends and mechanisms used for laundering money in the region is presented based on the typologies put forward by the Financial Action Task Force (FATF), the Financial Action Task Force on Money Laundering in South America (GAFISUD) and the Caribbean Financial Action Task Force (CFATF, also known as GAFIC in Spanish), as well as those emphasized in the Us Money Laundering Threat Assessment (United States Departament of the Treasury, Money Laundering Threat Assessment Working Group, 2005) conducted by the United States Department of Treasury in December 2005, and the United States Government's National Money Laundering Strategy (United States Departament of the Treasury, 2007). It then identifies the main international actors and their role in this struggle.

The following section provides an analysis of the key results of recent Mutual Evaluations conducted by specialized agencies to assess Latin American and Caribbean countries' compliance with the respective international standards. It also highlights some new money laundering typologies that emerge as a result of the creation of innovative financial products such as remittance payments by cell phones, internet transactions, the use of prepaid cards, and operations realized through the system of non-banking correspondents A case study of Mexico's recent performance is also presented. The paper's final section shares our conclusions on the current challenges of financial regulation in Latin America and the Caribbean.

The identification and documentation of current threats to the financial sector is a particularly salient topic in the light of the recent publication of the so called, Panama Papers, which has further highlighted the scale and scope of offshore accounts and shell corporations, among other financial sector risks. We include some reflections on emerging threats related to the financing of terrorism, and emphasize the need for innovative and coordinated international action to combat these critical issues and to ensure financial sector integrity and macroeconomic stability in the region. 


\section{BACKGROUND}

The phrase "money laundering" was officially coined by the us Government in the Money Laundering Control Act of 1986, which established it as a Federal crime. In 1988 the United States passed the Anti-Drug Abuse Act, introducing new restrictions and legislative support to prevent money laundering, including the obligation to maintain full information about and the identification of persons who acquire bearer documents or transfer amounts greater than three thousand dollars (3 000 USD). ${ }^{1}$ International efforts to combat money laundering were strengthened with the Vienna Convention in December 1988 and the Convention of the European Council in1990. The former introduced the obligation to criminalize the laundering of money derived from drug trafficking, and instituted the first measures to promote international cooperation, while the latter mandated support for the investigation and confiscation of illicit money originating from any type of criminal activity.

The negative effects of money laundering on the integrity of the financial system and the operational and reputational risks it posed for banks increasingly worried regulators. At the end of 1988, the Basel Committee issued its first statement against money laundering. In response to these growing concerns, the Group of Seven (G7), meeting at the Paris Summit in July 1989, established the Financial Action Task Force (FATF). ${ }^{2}$

Throughout the 1990s, Federal legislation in the United States was passed to fortify efforts in the fight against money laundering. The Uniting and Strengthening America by Providing Appropriate Tools to Restrict, Intercept and Obstruct Terrorism Act, more commonly known as the USDA Patriot Act - passed in 2001 after the attacks of September $11^{\text {th }}$ - further enhanced legislation against money laundering in the United States, and introduced the financing of terrorism as a Federal crime. It prohibited certain activities with "off-shore" banks without physical offices or affiliates in the USD, and significantly increased customer identification requirements. The Act also legislated for the possible ex-

\footnotetext{
${ }^{1}$ Currently the requirement for full identification and record keeping for money transfers at the international level is for transactions exceeding 1000 USD. As of October 2014, the United States was still working to comply with the international standard.

${ }^{2}$ The task force was created to examine and develop measures to combat money laundering. In October 2001, the FATF extended its mandate to include the design of measures to combat the financing of terrorism. To date the FATF has issued forty recommendations against money laundering and nine recommendations against the financing of terrorism.
} 
propriation of assets of illicit origin (United States Departament of the Treasury, Financial Crimes Enforcement Network, 2016).

Today, most related laws across countries incorporate a significantly wider concept of money laundering to include all types of financial documents (insurance, mortgages, government securities, bonds, etc.), goods, real estate, as well as gold and precious stones. This broader definition has fortified non-financial professionals' role in the fight against money laundering. Thus, recommendations for risk assessment in real estate and the buying and selling of precious metals, as well as guidelines for professionals such as lawyers and auditors have been produced by the FATF and other international expert groups to address these themes.

After September 11 $1^{\text {th }}, 2001$ most jurisdictions have also incorporated the crime of terrorist financing into their legislation. This is a more complex phenomenon to identify because the funds used in the financing of terrorism can come from assets of unlawful origin, but they may also be derived from assets of legal origin that have been channeled through various operations in the legal financial system. The latter carries a significantly higher risk for the financial system, given that the funds may come from perfectly legal operations or business, but be intended for terrorist activities. ${ }^{3}$

\section{THE INTEGRITY OF CAPITAL MARKETS AND FINANCIAL STABILITY, AND EFFECTS IN THE REAL SECTOR}

The process of money laundering comprises three phases: 1) the incorporation of products of illicit transactions, such as drug, human, and arms trafficking, kidnapping, tax evasion, corruption, etc. into the financial system; 2) as a second phase, a series of bank transactions and transfers are made to different accounts and jurisdictions in order to conceal the origin and location where the original infraction was committed, sending the transaction to another jurisdiction also makes it more difficult to monitor and later be retrieved by the relevant authorities, and 3) the third phase consists of the return of these resources which have been invested in business, real estate or assets of any nature, thus giving them the appearance of originating from legal operations. Money laundering and the financing of terrorism may adversely affect the overall health of

${ }^{3}$ This also involves the problem of who can identify or how one can establish the possibility that the risk of using the funds for terrorist activities is real. 
the economy and its financial stability ${ }^{4}$ by introducing distortions in the allocation of resources in such a way that investment decisions depend less on factor prices and profit return calculations, and more on criminal or illicit pressures. Moreover, through financial institutions, it has a triple negative effect (Bartlett, 2002):

a) It erodes the financial institutions involved because the entity can be defrauded by employees linked to laundering operations or because organized crime takes control over the financial entity (Financial Action Task Force, 2006).

b) It weakens public confidence in banking and non-banking financial institutions, thus limiting their impact on growth. Such institutions play a crucial role in the formation and allocation of capital, especially in developing economies. The successful reform of the financial system in these jurisdictions depends on sustained increases in depositor and investor confidence. Money laundering negatively impacts the reputation of banking entities, slows their ability to attract capital and affects their market value.

c) It reduces the chance of good corporate governance in financial institutions and increases operational risk in the absence of effective policies to combat money laundering. Conversely, policies against money laundering promote good corporate governance and reduce operational risk, thus contributing to the efficient functioning of banks and non-banking financial companies. This was recognized by the Basel Committee, which includes among its principles for effective banking supervision, key elements of a "know your client" policy. This is defined as a central element of internal control policies and risk management. ${ }^{5}$ The Basel Committee also addresses the issue of knowledge of the ultimate beneficiary of the property, ${ }^{6}$ an aspect that if not properly applied could ultimately allow a financial institution to be controlled by organized crime.

\footnotetext{
${ }^{4}$ This implies a condition where the financial system mechanisms for evaluating, transforming and managing financial risks (credit, liquidity, counterparty, market, etc.) functions well enough to contribute to the performance of the economy itself.

${ }^{5}$ Principles 14 and 15 of the Basel Committee for Effective Banking Supervision, and Publication 85 of the Committee on Customer Due Diligence.

${ }^{6}$ The glossary of the FATF methodology (Financial Action Task Force, 2013b) defines the ultimate beneficiary of the property as the natural person who ultimately owns or controls a customer and/or the person on whose behalf a transaction is made. It also includes persons who exercise effective control over a legal person or contract.
} 
There is yet a limited amount of literature on the direct effects of money laundering in the real sector of the economy. However, there is evidence that in addition to the indirect effects through the financial sector, money laundering may adversely affect productivity by generating perverse incentives that induce transactions not based on the normal market mechanisms for resource allocation via relative prices and profits (Bartlett, 2002). The most common case is real estate investment, where the increase in demand by money launderers induces higher market prices, thus leading all buyers to overpay for property assets and potentially generating "crowding-out" effects. ${ }^{7}$

There is also evidence of a strong correlation between low levels of compliance with international anti-money laundering standards and low tax collection, as well as with high levels of corruption. In relatively small countries, or in countries highly dependent on financial flows including those positioned as "off-shore" centers, money laundering can lead to significant market distortions.

In some cases the search for more flexible regulations has led to a suboptimal situation, where the possibility of money laundering is facilitated, with consequent negative effects on the country and the international community. Previous experience shows that jurisdictions with relaxed regulatory systems attract illicit money and tend to, at some point, face reputational problems that result in low business turnover and strong fluctuations in their levels of economic activity and employment. ${ }^{8}$

The relevance of anti-money laundering targets and actions to combat the financing of terrorism for national and international security has increased in the light of the current state of global affairs, marked by the emergence of new terrorist threats such as the Islamic State of Iraq and Syria (ISIS), and the resurgence and strengthening of new factions of established terrorist groups including those connected to Al Qaida and Al Shabaab, among others. Preempting the flow of money (of licit or illicit origin) to terrorist groups, drug and human traffickers, and other criminal entities that pose a threat to national and international security is an ever increasing priority. Cooperation at the national and international levels is of the utmost urgency from both government and private sectors.

\footnotetext{
${ }^{7}$ An exercise carried out for the Australian economy by John Walkers Consulting Services (1995) utilizing the country's input-output matrix, found that money laundering of between 5 billion of Australian dollars (AUD) and 10 billion AUD generated a loss of between 1.1 and $2.2 \%$ of gross domestic product in that year (between 5.6 billion AUD and 11.3 billion AUD).

${ }^{8}$ Case study of the British Virgin Islands, in Eastern Caribbean Central Bank, (1995).
} 


\section{METHODS AND TRENDS OF MONEY LAUNDERING AND THE FINANCING OF TERRORISM}

One of the essential tasks performed by FATF working groups, regional bodies similar to this one, the Egmont Group and Financial Intelligence Units (FIUs) of member countries is the identification of methods used by money launderers or those interested in financing terrorist operations. The main objective of identifying these methodologies is to create appropriate mechanisms to prevent them and alert financial institutions and regulators to the new and emerging trends of money launderers.

In 2005 the United States Government conducted the USD Money Laundering Threat Assessment (United States Departament of the Treasury, Money Laundering Threat Assessement Working Group, 2005). This document later served as the basis for the USD 2007 National Money Laundering Strategy (United States of the Treasury, 2007). The key points identified in the assessment are:

a) Banks remain the principal channel through which money laundering operations are performed. The incorporation of internet technology and remote banking presents new challenges for banks in terms of customer identification requirements and the identification of funding sources.

b) Money Services Businesses (MSBs), which include remittance agencies, exchange houses, vendors of traveler's checks, check cashing operations, etc., have a legal obligation in the United States to register with the Department of Treasury. However, less than $20 \%$ of MSBs comply with this regulation. As a result of the absence of "know your client" policies, MSBs have become one of the gateways to the financial system for money launderers and possibly for those interested in the financing of terrorism.

c) The smuggling of cash continues to be a primary channel for money launderers. A substitute for smuggling money has recently been the use of prepaid cards, in particular those that use an open system (United States of the Treasury, 2007). In this case, the card provider is not necessarily related to the provider of goods or services and in some cases obtaining cash directly from the prepaid cards is allowed.

d) Online Payment Systems: Given that is possible to make online payments between countries, this system presents prosecution difficulties 
for national authorities. Precious metals may also be used for payment, which opens an additional door to money launderers, especially when service providers accept payment in cash.

e) Informal Value Transfer Systems (IVTs): While these mechanisms have worked well over time as an efficient method for transferring funds between communities that have no access to formal financial services, they have recently been used for money laundering and terrorist financing, as the systems do not have identification requirements.

f) Money laundering based on trade is probably the best-known method and is mostly used for laundering funds from drug trafficking. In this typology, one of the mechanisms used is the Black Market Peso Exchange (BMPE), where the proceeds of criminal activities such as drug sales in the United States, are used to pay the obligations of an import company from another country ${ }^{9}$ in the United States. Meanwhile, the company pays the suppliers of the drugs in the country with local currency. Another way to launder money based on trade is through free trade zones. ${ }^{10}$ According to the FATF Typologies Report of November 2008, money laundering through the use of free zones in Latin America and the Caribbean has been detected.

g) Insurance Companies: Term life insurance and annuities have generated an opportunity for money launderers, primarily because insurers typically provide their products through brokers who usually do not have adequate controls, especially when operating in poorly or unregulated markets. Cases have been found where money launderers utilized the purchase of term life insurance to transfer illicit funds and only paid an insurance penalty for disinvesting before the expiration of the term.

h) Shell corporations ${ }^{11}$ and trusts represent another way to hide money derived from illicit activities. The use of shell corporations usually occurs in so-called "tax havens", since there are practically no registration re-

\footnotetext{
${ }^{9}$ Generally a company dedicated to smuggling goods.

${ }^{10}$ According to United States Departament of the State, Bureau for International Narcotics and Law Enforcement Affairs (2008). It says that in United States there are 250 free trade zone and money laundering issues have been identified in several of them.

${ }^{11}$ Produced on paper, also known as front operations that have no physical location, and are often created with false identification documents of owners, with minimal directors or corporate entities and bearer shares.
} 
quirements for companies in many of these jurisdictions. The most important omission perhaps of shell corporations is the identification of the rightful owners, especially through the use of anonymous companies with bearer shares. In Latin America, most countries now do not allow for the use of these instruments and FATF-like regional bodies are making joint efforts with regulatory agencies to ensure compliance with the FATF Recommendations in this regard. ${ }^{12}$ Trusts can serve an important lawful role; however, they also present money launderers with the advantage of not requiring registration with any financial authority in most jurisdictions. There have been transactions of this nature linked to corruption in some Latin American countries. One documented case detailed the creation of a series of shell companies and trusts that were used to purchase insurance companies in other jurisdictions with lax regulation. Money launderers then used these companies to drain the assets of the acquired insurance agencies into "off-shore" accounts, thus shortchanging the original policyholders (Financial Action Task Force, 2006).

i) Casinos represent an additional opportunity for money launderers because, currently, most of them provide other financial services such as deposit-taking, credit, funds transfers, check cashing and foreign exchanges. Online gaming and casinos allow players an extra level of anonymity and make it even more difficult for judicial authorities to track illicit transactions, given the ability to separate the place where the financial crime is committed from the place where it is reported or even where funds are ultimately delivered.

In Latin America and the Caribbean, the most important efforts in the identification of methodologies used by money launderers have been made by GAFISUD and the CFATF (Financial Action Task Force of South America, 2006; 2008; Caribbean Financial Action Task Force, 2008). These collective efforts represent an important input into the definition of guidelines for the competent authorities in order to protect their respective jurisdictions from the possibility that their systems could be used for money laundering or the financing of terrorism.

${ }^{12}$ In the United States there are two states that maintain the use of bearer shares, Nevada and Wyoming. Delaware has very simple requirements for business registration. 


\section{THE INTERNATIONAL COMMUNITY OF THE FIGHT AGAINST MONEY LAUNDERING AND THE FINANCING OF TERRORISM}

In recent years, the mandates of several international organizations, as well as national and multilateral financial institutions have been extended to incorporate efforts to combat money laundering and the financing of terrorism. As Chart 1 illustrates, the international community, including the United Nations and other international organizations such as the World Bank (wB), the International Monetary Fund (IMF), and regional development banks, together with the FATF and subsidiary regional-style bodies, plays a key role in combating money laundering and in developing strategies and guidelines for monitoring national compliance. Coupled with private sector expert groups such as the Wolfsberg and Egmont Groups and national institutions including financial regulators, and legislative and judicial bodies, international efforts to prevent money laundering and the financing of terrorism require a complex and coordinated commitment from multiple actors.

Chart 1. A Global Commitment in the Fight against Money Laundering and the Financing of Terrorism

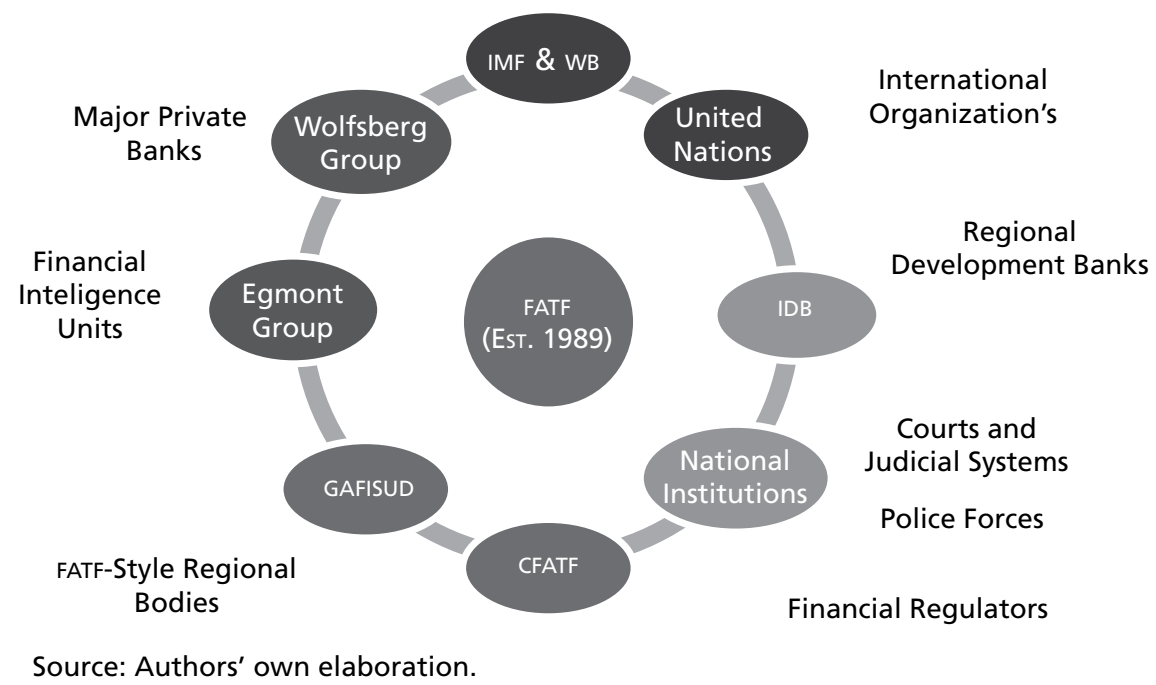

\section{Financial Action Task Force (FATF)}

The Financial Action Task Force (FATF) was created by the G7 in July 1989 with the specific mandate to design and promote compliance with international stan- 
dards for the prevention of money laundering. The FATF is composed of 34 jurisdictions and two regional organizations that together represent the majority of the world financial centers. ${ }^{13}$ Currently, in formal FATF meetings eight regional groups are involved as associate members, while 23 international organizations hold observer status. ${ }^{14}$ The Basel Committee formally joined as an observer in October 2008. The task force's fundamental work has focused on developing good practices against money laundering which have been incorporated into forty Recommendations, and recently updated with nine Regulations against the financing of terrorism (Chart 2). Of the $(40+9)$ Recommendations, six have been designated Core Recommendations, with an additional ten highlighted as Key Recommendations.

In detail, the 40 Recommendations to prevent money laundering describe:

a) The scope that money laundering must have within a country's legal system and the need to incorporate preventive and confiscation measures into existing regulatory codes.

b) The measures to be taken by financial institutions and non-financial businesses and professions to prevent money laundering (including customer due diligence policies, the definition and reporting of unusual or suspicious transactions, and preventative supervisory actions), and those to be taken by the international community in a compliance breach.

\footnotetext{
${ }^{13}$ FATF members include Argentina, Australia, Austria, Belgium, Brazil, Canada, China, Denmark, Finland, France, Germany, Greece, Hong Kong, China, Iceland, India, Ireland, Italy, Japan, Republic of Korea, Luxembourg, Mexico, the Netherlands, New Zealand, Switzerland, Norway, Portugal, Russian Federation, Singapore, South Africa, Spain, Sweden, Turkey, the United Kingdom and the United States. Regional Councils include The European Commission and The Gulf Cooperation Council.

${ }^{14}$ Participation by the Organization of American States (OAS) includes the Organization of American States/Inter-American Committee against Terrorism (OAS/CICTE) and the Organization of American States/Inter-American Drug Abuse Control Commission (OAS/CICAD). Participation by the United Nations includes representatives from the United Nations Office on Drugs and Crime (UNODC), United Nations Counter-Terrorism Committee Executive Directorate (UNCTED), The Analytical Support and Sanctions Monitoring Team to the Security Council Committee pursuant to resolutions 1267 (1999) and 1989 (2011) concerning Al-Qaida and associated individuals and entities, The Expert Group to the Security Council Committee established pursuant to resolution 1540 (2004), the Panel of Experts to the Security Council Committee established pursuant to resolution 1718 (2006), the Panel of Experts established pursuant to Security Council resolution 1929 (2010) and the Al-Qaida and Taliban Sanctions Committee (1267 Committee).
} 
c) The necessary institutional framework to be applied including the definition of competent authorities, and their respective powers and resources.

d) The role of international cooperation including a clear commitment to participate in mutual legal assistance, support the possibility of extradition and provide other forms of cooperation.

\section{Chart 2. FATF Recommendations and Good Practices $(40+9)$ Recommendations (2003 Recommendations and 2004 Amendments)}

\begin{tabular}{|c|c|}
\hline Core Recomendations & Key Recomendations \\
\hline $\begin{array}{l}\text { - R.1 Money laundering } \\
\text { criminalization } \\
\text { - R.5 Customer due } \\
\text { diligence } \\
\text { - R.10 Record keeping } \\
\text { - R.13 Suspicious } \\
\text { transactions report } \\
\text { - SR II Criminalizing the } \\
\text { financing of terrorism and } \\
\text { associated money } \\
\text { laundering } \\
\text { - SR IV Reporting suspicious } \\
\text { transactions related to } \\
\text { terrorism }\end{array}$ & $\begin{array}{l}\text { - R.3. Confiscation and } \\
\text { provisional measures } \\
\text { - R.4. Financial institution } \\
\text { secrecy laws } \\
\text { - R.23. Supervision } \\
\text { - R.26. Financial intelligence } \\
\text { units } \\
\text { - R.35. International } \\
\text { instruments } \\
\text { - R.36 Mutual legal } \\
\text { assistance } \\
\text { - R.40 Other forms of } \\
\text { international cooperation } \\
\text { - SR.I. Ratification and } \\
\text { implementation of UN } \\
\text { instruments } \\
\text { - SR.III. Freezing and } \\
\text { confiscating terrorist } \\
\text { assets } \\
\text { - SR.V. International } \\
\text { cooperation }\end{array}$ \\
\hline
\end{tabular}

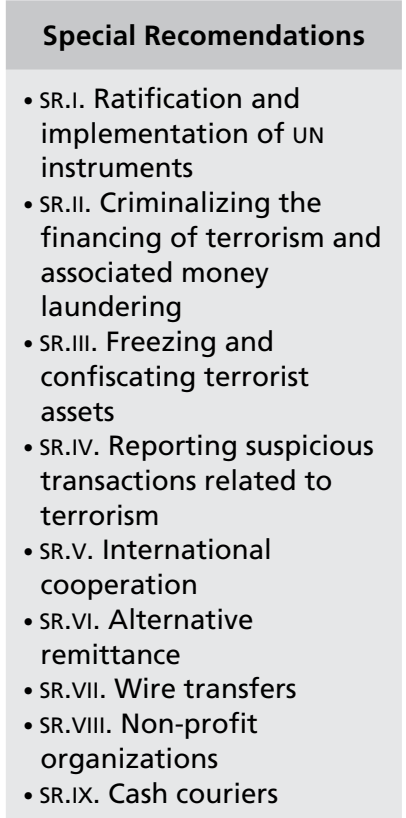

Source: Authors' elaboration based on Financial Action Task Force (2004).

Moreover, the special recommendations with regard to the prevention of the financing of terrorism contain a commitment to: 1) ratify and implement the relevant United Nations instruments; 2) criminalize offenses related to the financing of terrorism, terrorist acts and organizations; 3) enact legislation to facilitate the freezing of assets that could be intended for terrorist activities; 4) establish procedures for reporting suspicious transactions; 5) ensure the possibility of international cooperation and extradition; 6) hold all alternative systems for transferring funds to FATF standards and recommendations, particularly the requirement of "know your client" policies; 7) establish clear policies for custo- 
mer due diligence in bank transfers; 8) review the legal obligation of registration requirements for non-governmental organizations in order to prevent them from being used to divert resources to terrorist activities; and 9) establish control procedures for monitoring companies dedicated to the transport and movement of cash.

The United Nations Security Council recently issued a series of enhanced recommendations amid increased concerns for the financing of terrorist groups and the proliferation of weapons of mass destruction (United Nations Security Council, 2004; 2006a; 2006b; 2006c; 2006d; 2007; 2008a; 2008b; 2014). Resolution 1617 of the United Nations Security Council urges the international community to implement the $(40+9)$ Recommendations to combat money laundering and the financing of terrorism without delay. The FATF reacted by preparing guidelines for implementing relevant resolutions in each of its member jurisdictions. During their session on September 24th, 2014, the Security Council unanimously adopted Resolution 2178 in an effort to further crack down on the financing of international terrorist threats. In addition, the Resolution criminalized the act of traveling abroad to fight for extremist organizations, as well as recruiting for or providing funding to such terrorist groups.

The $(40+9)$ FATF Recommendations have been accepted by 180 jurisdictions and by the Boards of multilateral financial institutions such as the IMF, WB, the Asian Development Bank, and the African Development Bank. The Paris Declaration of 2002 played an important role in conferring sanctions on those countries identified as non-cooperative in the fight against money laundering by the FATF. Thereafter, a list of identified countries was established, and those countries were required to take appropriate measures and enact legislation in order to be removed from the list. The FATF remains willing to identify those countries that do not cooperate, and continuously reviews the progress of jurisdictions. In fact, in their meeting in October 2008 the FATF highlighted concerns about some countries, especially in terms of their commitment to support the fight against the financing of terrorism. The four main objectives of the FATF under its current mandate ${ }^{15}$ are to: 1$)$ review and clarify international standards (40 + 9 Recommendations); 2) promote the implementation of the Recommendations; 3) identify and generate adequate responses to new threats of money laundering and the financing of terrorism; and 4) establish working relationships with other members of the international community (Financial Action Task Force, 2008).

\footnotetext{
${ }^{15}$ The FATF mandate was revised and expanded in April 2008.
} 
During the meeting of Ministers of the FATF in April 2012, the mandate was unanimously extended to $2020,{ }^{16}$ focusing on the FATF's role as the international standard setting institution for efforts to combat money laundering, the financing of terrorism and the proliferation of weapons of mass destruction. The extended mandate reaffirms the close operational cooperation with the international community, and strengthens joint work with the FATF-style regional bodies. The most important task of the FATF is to assess compliance with international standards through a consistent process for each member jurisdiction. It continually develops methodological guidelines for evaluations to ensure each of the assessments follow a harmonized methodology. The evaluation process includes the preparation of questionnaires that are sent to the authorities of each country in advance so that evaluators are familiar with the established procedures prior to their Mutual Evaluation. During the country visit, consultations are conducted with national authorities, and also with relevant financial and non-financial private sector agencies and associated professionals. ${ }^{17}$ Once the visit has been concluded, the assessor group, with the support of the Technical Secretariat of the FATF, prepares a Mutual Evaluation report. ${ }^{18}$ The final document is submitted for discussion and approval in the FATF Assembly.

The FATF completed the third round of compliance assessments for each of its 34 member jurisdictions in 2011, though some members remain under a follow-up procedure. ${ }^{19}$ Identifying jurisdictions with deficiencies in their controls to preventing money laundering or the financing of terrorism, allows for support to be given to these countries to help mitigate these risks and protect the stability and security of the international community. In practice, the definition of a list of non-cooperating countries allowed more than twenty jurisdictions to receive FATF support and significantly improve their financial crime prevention schemes.

One of its important contributions has been the revision and adoption of a new set of Recommendations, which were approved in February 2012 following a joint process of consultation with the FATF-Style Regional Bodies and other international observers. The International Standards on Combating Money Laundering and the Financing of Terrorism \& Proliferation (Financial Action

\footnotetext{
${ }^{16}$ The new mandate was approved at the meeting of Ministers and representatives of the FATF in Washington, DC, on 20 April, 2012 (Financial Action Task Force, 2012a).

${ }^{17}$ This normally includes auditors and lawyers.

${ }^{18}$ Headquartered in Paris.

${ }^{19}$ The third round of Mutual Evaluations, conducted according to a standardized FATF methodology, was started in January 2005 and was completed in February 2011.
} 


\section{Chart 3. 2012 Revised FATF Recommendations (continued)}

\begin{tabular}{|c|c|c|}
\hline Rec. No. & \multicolumn{2}{|c|}{ Old Rec. No. } \\
\hline \multicolumn{3}{|c|}{ A - AML/CFT Policies and Coordination } \\
\hline 1 & - & Assessing risks and applying a risk-based approach ${ }^{a}$ \\
\hline 2 & R.31 & National cooperation and coordination \\
\hline \multicolumn{3}{|c|}{ B - Money Laudering and Confiscation } \\
\hline 3 & R.1 \& R. 2 & Money laundering offence ${ }^{a}$ \\
\hline 4 & R.3 & Confiscation and provisional measures ${ }^{a}$ \\
\hline \multicolumn{3}{|c|}{ C - Terrorist Financing and Financing Proliferation } \\
\hline 5 & SR.II & Terrorist financing offence ${ }^{a}$ \\
\hline 6 & SR. III & Targeted financial sanctions relation to terrorism $\&$ terrorist financing ${ }^{a}$ \\
\hline 7 & - & Targeted financial sanctions relation to proliferation \\
\hline 8 & SRVII & Non-profit organization \\
\hline \multicolumn{3}{|c|}{ D - Preventive Measures } \\
\hline 9 & R.4 & Financial institution secrecy laws \\
\hline \multicolumn{3}{|c|}{ Customer due diligence and record keeping } \\
\hline 10 & R.5 & Customer due diligence ${ }^{a}$ \\
\hline 11 & R.10 & Record keeping \\
\hline \multicolumn{3}{|c|}{ Additional measures for specific customers and activities } \\
\hline 12 & R.6 & Politically exposed persons ${ }^{a}$ \\
\hline 13 & R.7 & Correspondent banking ${ }^{a}$ \\
\hline \multicolumn{3}{|c|}{ Additional measures for specific customers and activities } \\
\hline 14 & SR. VI & Money or value transfer services ${ }^{a}$ \\
\hline
\end{tabular}

Task Force, 2012) synthesize the previous $(40+9)$ Recommendations, seeking to tighten legislation and strengthen compliance. These new Recommendations place a special emphasis on creating transparency, preventing corruption and managing the risks of new and emerging threats to financial sector stability.

Of particular relevance given the current global state of affairs is the challenge of combating terrorist financing. Most anti-money laundering and counter-terrorist financing strategies have been mainstreamed throughout the new Recommendations, replacing the need for a set of Special Recommendations; however, Section C applies a specific focus to combat the financing of terrorism and the proliferation of weapons of mass destruction. The 2012 Recommendations (Chart 3) are set to be applied uniformly in the upcoming fourth round of Mutual Evaluations, that will be conducted in two jointly re-enforcing components: a Technical Compliance Assessment to measure the level of conformity with the revised standards, and an Effectiveness Assessment, which will rely on 
24 ECONOMÍA: TEORÍA Y PRÁCTICA • Nueva Época, número 44, enero-junio 2016

\section{Chart 3. 2012 Revised FATF Recommendations (concludes)}

\begin{tabular}{|c|c|c|}
\hline Rec. No. & \multicolumn{2}{|l|}{ Old Rec. No. } \\
\hline \multicolumn{3}{|c|}{ Additional measures for specific customers and activities } \\
\hline 15 & R.8 & New technologies \\
\hline 16 & SR. VII & Wire transfers ${ }^{a}$ \\
\hline \multicolumn{3}{|c|}{ Reliance controls and financial groups } \\
\hline 17 & R.9 & Reliance on third parties ${ }^{a}$ \\
\hline 18 & R. 15 \& R.22 & Internal controls and foreign branches and subsidiaries \\
\hline 19 & R.21 & Higher-risk countries ${ }^{a}$ \\
\hline \multicolumn{3}{|c|}{ Reporting of suspicious transactions } \\
\hline 20 & R.13 \& SR.IV & Reporting of suspicious transactions ${ }^{a}$ \\
\hline 21 & R.14 & Tipping-off confidentiality \\
\hline \multicolumn{3}{|c|}{ Designated non-financial Businesses and Professions (DNFBPS) } \\
\hline 22 & R. 12 & DNFBPS: Customer due diligence ${ }^{a}$ \\
\hline 23 & R.16 & DNFBPS: Other measures ${ }^{a}$ \\
\hline \multicolumn{3}{|c|}{ E - Transparency and Beneficial Ownership of Legal Persons and Arrangements } \\
\hline 24 & R.33 & Transparency and beneficial ownership of legal persons ${ }^{a}$ \\
\hline 25 & R.34 & Transparency and beneficial ownership of legal arrangements ${ }^{a}$ \\
\hline \multicolumn{3}{|c|}{ F - Powers and Responsabilities of Competent Authorities and Other Institutional Measures } \\
\hline \multicolumn{3}{|c|}{ Regulation and supervision } \\
\hline 26 & R.23 & Regulation and supervision of financial institutions ${ }^{a}$ \\
\hline 27 & R.29 & Powers of supervisors \\
\hline 28 & R.24 & Regulation and supervision of DNFBPS \\
\hline \multicolumn{3}{|c|}{ Operational and Law Enforcement } \\
\hline 29 & R.26 & Financial intelligence units ${ }^{a}$ \\
\hline 30 & R.27 & Responsibilities of law enforcement and investigative authorities ${ }^{a}$ \\
\hline 31 & R.28 & Powers of law enforcement and investigative authorities \\
\hline 32 & SR.IX & Cash couriers ${ }^{a}$ \\
\hline \multicolumn{3}{|c|}{ General requirements } \\
\hline 33 & R.32 & Statistics \\
\hline 34 & R.25 & Guidance and feedback \\
\hline \multicolumn{3}{|c|}{ Sanctions } \\
\hline 35 & R. 17 & Sanctions \\
\hline
\end{tabular}

\section{G - International Cooperation}

\begin{tabular}{lll}
36 & R.35 \& SR.I & International instruments \\
\hline 37 & R.36 \&SR.V & Mutual legal assistance \\
38 & R.38 & Mutual legal assistance: freezing and confiscation ${ }^{\text {a }}$ \\
\hline 39 & R.39 & Extradition \\
40 & R.40 & Other forms of international cooperation \\
\end{tabular}

${ }^{a}$ This Recommendations have interpretive notes, which should be read in conjunction with the Recommendation.

Source: Authors' elaboration based on Financial Action Task Force (2012). 
the judgment of the assessors, taking into account national context and the effective level of risk (Financial Action Task Force, 2013a). The assessment of a country will result in two sets of ratings: "Technical Compliance" which ranges from Compliant to Non-Compliant, and "Effectiveness" from High to Low. ${ }^{20}$ Such fourth round began in late 2013 with the assessments of Australia, Belgium, Norway and Spain to be finished by 2015 .

\section{Regional groups similar to the FATF}

Globally, compliance with the FATF $(40+9)$ Recommendations relies on support from the so-called FATF Style Regional Bodies (FSRBS). ${ }^{21}$ These regional groups act similarly to the FATF, disseminating information and training assessors in the implementation of evaluation methodologies in each of their respective member jurisdictions. Their geographical distribution allows them to perform the important job of identifying risks and emerging typologies, ${ }^{22}$ sometimes identifying ones that are regionally specific (Caribbean Financial Action Task Force, 2008; Financial Action Task Force of South America, 2006; 2008). Another important contribution of the FSRBS has been supporting countries in the drafting of laws and regulations that comply with international standards.

As in the case of the FATF, their most important task is to conduct Mutual Evaluations for member jurisdictions in order to identify potential weaknesses in their national protection schemes, and to support countries in finding appropriate mechanisms to address them. Countries of Latin America and the Caribbean are members of either the Caribbean Financial Action Task Force (CFATF, or GAFIC in Spanish) or the Financial Action Task Force on Money Laundering in South America (GAFISUD). Some jurisdictions also participate directly as members of the FATF. ${ }^{23}$ In some cases, assessments have been conducted with the support of the IMF, through their Financial Sector Assessment Program (FSAP) and in others with the support of the wB. The third round of Mutual Evaluations for all

\footnotetext{
${ }^{20}$ For a full description of the revised methodology see Financial Action Task Force (2013b).

${ }^{21}$ These groups include the Financial Action Task Force on Money Laundering in South America, Caribbean Financial Action Task Force, Asia Pacific Group on Combating Money Laundering, the Eurasian Group, the Eastern and Southern Africa Anti-Money Laundering Group, the Intergovernmental Action Group against Money Laundering in West Africa, and the Middle East and North Africa Financial Action Task Force.

${ }^{22}$ Methodologies commonly used by money launderers or those who finance terrorism.

${ }^{23}$ Latin American and Caribbean countries that are members of the FATF include Argentina, Brazil and Mexico.
} 
Latin American and Caribbean countries performed by CFATF and GAFISUD was concluded in 2013.

\section{Egmont Group}

In 1995 a group of Financial Intelligence Units (FIUs) ${ }^{24}$ gathered in Brussels, Belgium established an informal cooperation network called the Egmont Group, named after the location of their initial meeting at the Egmont Aremberg Palace. Since then, the Egmont Group has met formally on an annual basis, and today operates with the support of a Technical Secretariat based in Canada. This has allowed the Group to establish formal procedures for operational information exchange, the promotion of best practices and training. Currently, there are 108 countries with FIUs recognized by the Egmont Group, who been divided into five working groups. One of the most important results has been the negotiation of bilateral agreements to exchange information among members, which allows for the tracking of international money laundering or the financing of terrorism.

\section{Wolfsberg Group}

The Wolfsberg Group emerged as an initiative of eleven global banks ${ }^{25}$ for the purpose of elaborating policy standards aimed at preventing money laundering and the financing of terrorism in the financial services industry, taking into consideration the characteristics of the business and looking to mitigate the impact of these threats on productivity. The Group derives its name, from the place of its first meeting, at the Wolfsberg Castle in Switzerland, where they met to draft procedural guidelines for the prevention of money laundering through private banking operations. In 2007 the Wolfsberg Group issued its statement against corruption and a subsequent document in 2011, which identifies some of the measures that financial institutions can take to prevent bribery and fraud. In addi-

\footnotetext{
${ }^{24}$ As the explanatory note of the Egmont Group of Financial Intelligence Units states, a FIU is a central government agency responsible for receiving, (as required and permitted by law), analyzing, and distributing among the competent authorities, information about transactions suspected of having illicit origins, those directed to the financing of terrorism, or any other information necessary to combat money laundering and the financing of terrorism according to the relevant legislation. The FIU s may have an administrative character (usually in the Superintendency of Banks), or belong to the Judicial Investigation Agencies or Police Departments (Egmont Group, 2016).

${ }^{25}$ Banco Santander, Bank of Tokyo-Mitsubishi UfJ, Barclays, Citigroup, Credit Suisse, Deutsche Bank, Goldman Sachs, HSBC, JP Morgan Chase, Societé Générale and uBs.
} 
tion, the Group is currently working with the Society for Worldwide Interbank Financial Telecommunication (SWIFT ${ }^{26}$ membership and regulatory bodies to incorporate preventative measures in SWIFT messages to protect the global system of payments (Wolfsberg Group, 2016).

\section{United Nations (UN)}

In 1988 the United Nations Convention against Illicit Traffic in Narcotic Drugs and Psychotropic Substances (Vienna Convention) was adopted, which incorporated a call for the criminalization of money laundering. In 1998 the UN Political Declaration and Action Plan against Money Laundering was adopted, and in December 2000 the un Convention against Transnational Organized Crime was agreed in Palermo, Italy. This convention also called for the criminalization of money laundering, and focused on issues of mutual legal assistance, international cooperation, joint research among countries and extradition. As part of these efforts, and to comply with the provisions of the Vienna Convention, the Global Programme against Money Laundering, Proceeds of Crime and the Financing of Terrorism (GPML) ${ }^{27}$ was created as a part of the Law Enforcement, Organized Crime and Anti-Money Laundering Unit of the UN Office on Drugs and Crime.

In late September 2001 the United Nations Security Council adopted Resolution 1373 which provided a primary legal basis for the prevention of the financing of terrorism at the international level. This resolution entered into force in April 2002. At the same time, the Security Council also created the CounterTerrorism Committee responsible for monitoring the implementation of this resolution by UN members States. In September 2006 the United Nations Global Counter-Terrorism Strategy was adopted, including a call for Member States to fully implement the comprehensive international standards embodied in the forty Recommendations of the FATF on money laundering and the nine Special Recommendations on the financing of terrorism. ${ }^{28}$ The UN Strategy recognizes the sup-

\footnotetext{
${ }^{26}$ SWIFT is an interbank cooperative established in Belgium. Through its membership it conducts banking operations and exchanges information. It comprises more than 8300 banking organizations, securities firms, and corporate customers in 208 countries.

${ }^{27}$ The objective of the GPML is to contribute to the strengthening and ability of Member States to implement measures against money laundering and the financing of terrorism and to provide technical support and assistance for detecting and confiscating the proceeds of illegal activities, as required in the relevant United Nations instruments and international standards.

${ }^{28}$ The action plan for the Resolution was approved by the General Assembly on September 8th, 2006 (United Nations 2006).
} 
port required by some States in the implementation of the $(40+9)$ FATF Recommendations. Consistent with that recognition, the FATF follows up on the issued resolutions and produces corresponding implementation guides. ${ }^{29}$ In addition, the FATF provides technical support for their application in various countries, particularly in developing countries.

\section{Organization of American States}

The Inter-American Drug Abuse Control Commission (CICAD), a specialized agency of the Organization of American States (OAS), was created in 1986 with the aim of reducing the production, trafficking and abuse of drugs. As part of its strategy, in 1999, CICAD created the Anti-Money Laundering Section (AML) that focuses its efforts on providing support and technical assistance to supervisors and administrators of justice in the Americas. OAS-CICAD has contributed significantly to the creation and implementation of FIUs, and with the support of the Inter-American Development Bank (IDB) has organized various training programs for FIU staff, judges and prosecutors in the region. The Inter-American Committee against Terrorism (CICTE), a specialized committee of the OAS, was created in 1999 with an aim to promote cooperation among Member States to prevent, combat and eliminate terrorism. CICTE participates as an observer in meetings of the FATF. The CICTE Secretariat has initiated a series of technical assistance and capacity building initiatives to support the region in the prevention and elimination of terrorism, including targeted programs on border and financial controls, the protection of critical infrastructure, crisis management programs and the drafting of national polices in coordination with international, regional and sub-regional institutions and relevant private sector actors. In 2002 under the guidance of CICTE, Member States adopted the Inter-American Convention against Terrorism, which entered into force in July 2003.

\section{International Monetary Fund and the WB}

One of the most important monitoring activities that the International Monetary Fund (IMF) developed in the recent past is derived from the country's Financial

${ }^{29}$ The latest guide is the guide for the implementation of the financial aspects included in 1803 Resolution of the United Nations Security Council (2008a), referring to the non-proliferation of weapons of mass destruction. 
Sector Assessment Program (FSAP). Since 2001, recognizing the risk imposed by money laundering and the financing of terrorism on the integrity and stability of the financial system, the IMF has incorporated an assessment of countries' regulations and compliance with FATF recommendations in their FSAP reports. ${ }^{30}$ This enables the Fund to provide support to their members to overcome regulatory weaknesses, and assist countries that have adopted legislation to combat money laundering and the financing of terrorism, but face problems in implementation.

The WB, recognizing the inverse relationship between money laundering and financial stability, gives technical assistance to developing countries in the implementation of the $(40+9)$ Recommendations. At the same time, it incorporates the IMF's compliance assessments into their broader financial system assessments. The WB also provides support for the design of appropriate legal norms and regulations to ensure that they are adjusted to international standards (International Monetary Fund and World Bank, 2001). Under the Action Plan to Prevent Money Laundering and the Financing of Terrorism, the wB has initiated a staff training program to prepare officers to adequately address these issues with countries.

\section{Asian Development Bank}

The Asian Development Bank (ADB) based its strategy for the prevention of money laundering and the financing of terrorism on their programs to support the financial sectors of countries in the region, linking sector loan disbursements to the requirement that some decisions or policies supporting the development of laws to regulate these issues are adopted. The Anti-Money Laundering and Financing of Terrorism Policy approved by the Board of the Asian Development Bank (2003) incorporates the following elements: 1) support member countries

\footnotetext{
${ }^{30}$ Part of the evaluation of codes and standards by the WB and IMF is based on the identification of twelve international standards relevant to their areas of work: 1) Transparency of data; 2) Fiscal transparency; 3) Transparency of monetary and financial policies developed by the IMF; 4) Principles for effective banking supervision, Basel Committee; 5) Objectives and principles for the supervision of the securities market, IOSCO; 6) Insurance supervision principles, IAIS; 7) Basic principles for payment systems, the Committee on Payment and Settlement Systems; 8) $(40+9)$ Recommendations against money laundering and the financing of terrorism by the FATF; 9) Principles of business management, OECD; 10) International accounting standards, International Accounting Standards Committee Board; 11) International auditing standards of the International Federation of Accountants; and 12) Insolvency and creditor rights of the United Nations Commission on International Trade law.
} 
in their efforts to establish effective legal and institutional frameworks for the prevention of money laundering and the financing of terrorism; 2) increase coordination and collaboration with other agencies and international organizations; 3) strengthen internal controls to safeguard the resources of the Asian Development Bank; and 4) strengthen staff capacities in these areas, according to the policy review in April 2008 (Asian Development Bank, 2008).

\section{African Development Bank}

Since October 2007, the African Development Bank (AFDB) has strengthened its policy against money laundering and the financing of terrorism with the adoption of its Bank Group Strategy for the Prevention of Money Laundering and Terrorist Financing in Africa (African Development Bank, 2009). The Strategy emphasizes the need to comply with the $(40+9)$ FATF Recommendations, as well as to assist member countries in the creation and implementation of appropriate legislation. The resolution also emphasizes the need for risk mitigation to ensure that the Bank's resources are used for their intended purposes by Member States.

\section{Inter-American Development Bank}

The Inter-American Development Bank (IDB) developed several joint projects with GAFISUD, CFATF and the OAS-CICAD as part of the efforts to support the region and to ensure that some of the countries that had been listed by the FATF as noncompliant were able to improve their conformity with international standards and develop their own schemes to fight money laundering and the financing of terrorism. The IDB supported the design of new regulations in Panama and Guatemala, and the establishment of relevant FIUs. Additionally, the IDB has participated in technical assistance projects for the training of judicial officers in joint projects with FSRBS and the OAS-CICAD.

\section{CURRENT SITUATION AND NEW CHALLENGES FOR REgUlation AND SUPERVISION IN LATIN AMERICA AND THE CARIBBEAN}

The most important task assigned to the FATF is the assessment of countries' compliance with the $(40+9)$ Recommendations, through the use of a homogeneous methodology. In the case of Latin America and the Caribbean, evaluations are conducted by GAFISUD, the CFATF or the IMF. In the latter case, evaluations are 
then submitted for approval to the FATF or a FSRB to ensure their consistency. Assessments for Brazil, Argentina and Mexico are conducted directly by the FATF. In all cases three rounds of Mutual Evaluations have been completed with satisfactory progress, as most countries have made significant efforts to prevent the risk of money laundering and the financing of terrorism. Today no country in Latin America and the Caribbean remains on the FATF list of countries with a high risk of money laundering or terrorist financing. Globally, Iran and the Democratic People's Republic of Korea (North Korea) remain on this list, with particular concern for their failure to combat the financing of terrorism and money laundering, noting the serious threats these pose to international financial system security.

In its statement in June 2014, the FATF identified jurisdictions with strategic deficiencies in their compliance with anti-money laundering and counter-terrorist financing efforts and who have not made sufficient progress and/or have not committed to an action plan with the FATF (Financial Action Task Force, 2014a). ${ }^{31}$ The FATF and GAFISUD note that Ecuador has taken steps towards improving its anti-money laundering and counter-terrorist financing regime, including by enacting a new criminal code, which includes provisions to adequately criminalize money laundering and terrorist financing. However, despite Ecuador's high-level political commitment to the FATF and GAFISUD, the country has not made sufficient progress in implementing its action plan, and certain strategic deficiencies remain, particularly with respect to procedures for identifying and freezing terrorist assets. This does not mean, however, that deficiencies do not still exist in some countries in their effective implementation of the Recommendations. Next, a summary of compliance with the $(40+9)$ Recommendations in Latin America and the Caribbean is presented. This analysis is based on publicly available information from the websites of the FATF, the CFATF and GAFISUD, and is derived from countries' respective third Round Mutual Evaluation Reports.

Chart 4 shows that the majority of countries in the region still face shortcomings in their compliance with the $(40+9)$ Recommendations. In fact, 33 of the 42 countries surveyed in the region, were rated Non-Compliant or Partially Compliant with more than $50 \%$ of FATF Recommendations. Of these, ten countries (Argentina, Bolivia, Dominica, Dominican Republic, Guyana, Haiti, St. Lucia, Suriname, Trinidad and Tobago, and Turks and Caicos) were rated

${ }^{31}$ Other Jurisdictions with strategic anti-money laundering and counter-terrorist financing deficiencies that have not made sufficient progress in compliance include: Algeria, Indonesia and Myanmar. 
32 ECONOMÍA: TEORÍA Y PRÁCTICA • Nueva Época, número 44, enero-junio 2016

Chart 4. Latin America and the Caribbean: Compliance with FATF $(40+9)$ Recommendations*

(continued)

\begin{tabular}{|c|c|c|c|c|c|c|c|c|}
\hline Country & $\begin{array}{l}\text { Recs. } \\
\text { Rated } \\
\text { C/LC }\end{array}$ & $\begin{array}{l}\text { Recs. } \\
\text { Rated } \\
\text { PC/NC }\end{array}$ & $\begin{array}{l}\text { Recs. Not } \\
\text { Applicable }\end{array}$ & $\begin{array}{l}\text { Core } \\
\text { Recs. }^{\text {a }} \\
\text { Rated } \\
\text { C/LC }\end{array}$ & $\begin{array}{l}\text { Core } \\
\text { Recs. } \\
\text { Rated } \\
\text { PC/NC }\end{array}$ & $\begin{array}{l}\text { Key } \\
\text { Recs. }{ }^{b} \\
\text { Rated } \\
\text { C/LC }\end{array}$ & $\begin{array}{l}\text { Key } \\
\text { Recs. } \\
\text { Rated } \\
\text { PC/NC }\end{array}$ & $\begin{array}{l}\text { Rating on R.5. } \\
\text { Customer Due } \\
\text { Diligence }\end{array}$ \\
\hline Anguilla & 28 & 21 & 0 & 3 & 3 & 8 & 2 & PC \\
\hline Antigua and Barbuda & 14 & 35 & 0 & 0 & 6 & 5 & 5 & PC \\
\hline Argentina & 3 & 46 & 0 & 0 & 6 & 0 & 10 & NC \\
\hline Aruba & 9 & 38 & 2 & 2 & 4 & 1 & 9 & NC \\
\hline Bahamas & 22 & 27 & 0 & 2 & 4 & 6 & 4 & PC \\
\hline Barbados & 22 & 27 & 0 & 4 & 2 & 3 & 7 & PC \\
\hline Belize & 11 & 38 & 0 & 0 & 6 & 2 & 8 & NC \\
\hline Bermuda & 19 & 30 & 0 & 2 & 4 & 6 & 4 & NC \\
\hline $\begin{array}{l}\text { Bolivia } \\
\text { (Plurinational State of) }\end{array}$ & 5 & 44 & 0 & 1 & 5 & 2 & 8 & PC \\
\hline Brazil & 24 & 23 & 2 & 3 & 3 & 4 & 6 & PC \\
\hline British Virgin Islands & 33 & 16 & 0 & 5 & 1 & 9 & 1 & PC \\
\hline Cayman Islands & 38 & 11 & 0 & 5 & 1 & 10 & 0 & PC \\
\hline Chile & 23 & 26 & 0 & 4 & 2 & 6 & 4 & PC \\
\hline Colombia & 40 & 9 & 0 & 5 & 1 & 8 & 2 & PC \\
\hline Costa Rica & 11 & 37 & 1 & 1 & 5 & 4 & 6 & PC \\
\hline Curaçao & 25 & 24 & 0 & 2 & 4 & 5 & 5 & PC \\
\hline Dominica & 7 & 42 & 0 & 1 & 5 & 2 & 8 & NC \\
\hline Dominican Republic & 8 & 40 & 1 & 0 & 6 & 2 & 8 & PC \\
\hline Ecuador & 14 & 35 & 0 & 1 & 5 & 4 & 6 & PC \\
\hline El Salvador & 23 & 26 & 0 & 4 & 2 & 7 & 3 & PC \\
\hline Grenada & 13 & 36 & 0 & 1 & 5 & 5 & 5 & NC \\
\hline Guatemala & 29 & 20 & 0 & 5 & 1 & 6 & 4 & PC \\
\hline Guyana & 6 & 43 & 0 & 0 & 6 & 0 & 10 & PC \\
\hline Haiti & 7 & 41 & 1 & 1 & 5 & 1 & 9 & NC \\
\hline Honduras & 12 & 37 & 0 & 4 & 2 & 2 & 8 & NC \\
\hline Jamaica & 30 & 18 & 1 & 1 & 5 & 8 & 2 & PC \\
\hline Mexico & 24 & 25 & 0 & 1 & 5 & 6 & 4 & PC \\
\hline Montserrat & 28 & 21 & 0 & 4 & 2 & 6 & 4 & PC \\
\hline Nicaragua & 11 & 37 & 1 & 2 & 4 & 4 & 6 & PC \\
\hline Panama & 39 & 10 & 0 & 6 & 0 & 9 & 1 & LC \\
\hline
\end{tabular}


Chart 4. Latin America and the Caribbean: Compliance with FATF $(40+9)$ Recommendations*

(concludes)

\begin{tabular}{|c|c|c|c|c|c|c|c|c|}
\hline Country & $\begin{array}{l}\text { Recs. } \\
\text { Rated } \\
\text { C/LC }\end{array}$ & $\begin{array}{l}\text { Recs. } \\
\text { Rated } \\
\mathrm{PC} / \mathrm{NC}\end{array}$ & $\begin{array}{l}\text { Recs. Not } \\
\text { Applicable }\end{array}$ & $\begin{array}{l}\text { Core } \\
\text { Recs. }^{\text {a }} \\
\text { Rated } \\
\text { C/LC }\end{array}$ & $\begin{array}{l}\text { Core } \\
\text { Recs. } \\
\text { Rated } \\
\text { PC/NC }\end{array}$ & $\begin{array}{l}\text { Key } \\
\text { Recs. }^{\mathrm{b}} \\
\text { Rated } \\
\text { C/LC }\end{array}$ & $\begin{array}{l}\text { Key } \\
\text { Recs. } \\
\text { Rated } \\
\text { PC/NC }\end{array}$ & $\begin{array}{l}\text { Rating on R.5. } \\
\text { Customer Due } \\
\text { Diligence }\end{array}$ \\
\hline Paraguay & 18 & 30 & 1 & 2 & 4 & 5 & 5 & PC \\
\hline Peru & 34 & 14 & 1 & 6 & 0 & 5 & 5 & LC \\
\hline Saint Maarten & 16 & 33 & 0 & 1 & 5 & 1 & 9 & PC \\
\hline St. Kitts and Nevis & 16 & 33 & 0 & 1 & 5 & 2 & 8 & NC \\
\hline St. Lucia & 3 & 45 & 1 & 0 & 6 & 0 & 10 & NC \\
\hline $\begin{array}{l}\text { St. Vincent and the } \\
\text { Grenadines }\end{array}$ & 21 & 28 & 0 & 2 & 4 & 6 & 4 & NC \\
\hline Suriname & 5 & 43 & 1 & 0 & 6 & 1 & 9 & NC \\
\hline Trinidad and Tobago & 7 & 42 & 0 & 0 & 6 & 1 & 9 & NC \\
\hline Turks and Caicos & 10 & 39 & 0 & 0 & 6 & 4 & 6 & NC \\
\hline Uruguay & 17 & 32 & 0 & 2 & 4 & 3 & 7 & NC \\
\hline $\begin{array}{l}\text { Venezuela (The } \\
\text { Bolivarian Republic of) }\end{array}$ & 18 & 31 & 0 & 1 & 5 & 5 & 5 & PC \\
\hline
\end{tabular}

${ }^{*} \mathrm{C}=$ Compliant, $\mathrm{LC}=$ Largely Compliant, $\mathrm{PC}=$ Partially Compliant, and NC = Not Compliant.

a Core Recommendations include: R.1, R.5, R.10, R.13, R.II and R.IV.

${ }^{b}$ Key Recommendations include: R.3, R.4, R.23, R.26, R.35, R.36, R.40, R.I, R.III, and R.V.

Note: Ratings reflect compliance in each country's respective Third Round Mutual Evaluation Report (MER).

Source: Data compiled from Financial Action Task Force (n.d.), Caribbean Action Financial Action Task Force (n.d.) and Financial Action Task Force of South America (n.d.).

Non-Compliant or Partially-Compliant with more than $80 \%$ of the Recommendations. Based on the results of their third Round Mutual Evaluations, these countries would require support in their efforts to combat money laundering and the financing of terrorism Guayana and Panama were also listed as jurisdictions with strategic deficiencies.

In order to fortify countries' efforts, particular attention should be applied to their compliance rates with Core and Key Recommendations. In Latin America and the Caribbean, nine countries were rated Non-Compliant wit all six Core Recommendations, among them: Antigua and Barbuda, Argentina, Belize, Dominican Republic, Guyana, St. Lucia, Suriname and Trinidad and Tobago and Turks and Caicos. In contrast only Panama and Peru were rated Complaint and/ or Largely Compliant with all six Core Recommendations. The real test for many countries will be in their upcoming fourth Round Mutual Evaluations, which 
will stress not only the existence of national laws and regulations, but also their application and effectiveness. That is to say, the majority of countries in the region face shortcomings in compliance with Core FATF regulations.

With regard to compliance with the ten Key Recommendations, overall, the region failed to perform better. With the exception of Anguilla, the British Virgin Islands, the Cayman Islands, Colombia, Jamaica and Panama, who had compliance rates of more than $80 \%$, the majority of the region struggled to comply. Performance was again particularly troubling in Argentina, Guyana and St. Lucia (who failed to comply with any of the ten Key Recommendations) and Aruba, Belize, Bolivia, Dominica, Dominican Republic, Haiti, Honduras, Saint Maarten, St. Kitts and Nevis, Suriname, and Trinidad and Tobago (who rated Non-Compliant or Partially Compliant with more than $80 \%$ of the Key Recommendations).

The cases in which less than $40 \%$ of the Core and Key Recommendations are met require special attention. Based on the results of the third Round Mutual Evaluations, $50 \%$ of countries in the region had compliance levels below this threshold. This is particularly true when there are deficiencies in the implementation of Recommendations 5 and 23. With respect to Recommendation 5 on customer due diligence, only Panama and Peru were rated as Largely Compliant with the FATF Regulation, while more than one-third of all countries in the region were rated Non-Compliant with this critical recommendation.

In the case of Panama, this is the result of an agreed working plan to leave the gray list of non-compliant countries. When viewed together, compliance with Recommendations 5 and 23, serve as central pillars of a country's financial system and strategy to combat money laundering and the financing of terrorism. Here the Caribbean nations faced serious issues in fulfilling the FATF regulations, with Aruba, Bermuda, Dominica, Haiti, St. Lucia, St. Vincent and the Grenadines, Suriname, Trinidad and Tobago, as well as Honduras rating Non-Compliant on both Recommendations 5 and 23 .

Given the typologies of money laundering found in the region, it can be concluded that while countries have made significant progress in the implementation of the $(40+9)$ FATF Recommendations, there is still a gap in Latin America and the Caribbean with respect to international norms. Additionally, the emergence of new forms of money laundering and the financing of terrorism requires that policies and countries' regulatory frameworks be periodically reviewed in order to reflect recent developments. One of the biggest regional challenges is the emergence of new forms of money laundering that rely on advanced techno- 
logical platforms or innovations, including remittance payments by cell phones, and the proliferation of web-based international financial services, the use of pre-paid credit cards, and the proliferation of non-banking correspondents. Moreover, in countries that lack adequate regulation, there is a risk that non-governmental organizations and trusts are used for money laundering. It is also noteworthy that there are still some Latin American and Caribbean countries that do not meet most of the Key and Special Recommendations to counter the financing of terrorism and weapons of mass destruction. Emerging threats in this regard often stem from the operations of transnational organized crime groups, including drug trafficking networks. Advances in online technology also pose new risks for the financing of terrorist organizations, rogue criminal regimes and breakaway nations.

As highlighted previously, notwithstanding certain advances, such as the success of Panama in being removed from the gray list in February 2016, there remains significant room for improvement with regard to legal compliance and implementation. The Panama Papers prove that the next challenge for the region in terms of anti-money laundering and counter-terrorist financing efforts will be during the upcoming fourth Round Mutual Evaluations, which will measure countries' continued application of international norms, as well as their performance with respect to the revised FATF Regulations adopted in 2012 that underline effectiveness of the approved legislation. With the emergence of new international issues and threats to financial system stability, Latin America and the Caribbean countries together as a region will have to strengthen multi-lateral cooperation and improve their capacities to jointly address these risks.

\section{MEXICO'S COMPLIANCE WITH THE FAFT $(40$ + 9 ) RECOMMENDATIONS}

Mexico, the second largest economy in Latin America and the Caribbean, is a member of both the FATF and the CFATF. Given the country's importance in the region, as well as its integration into the global economic system through trade relationships and economic cooperation, Mexico provides a particularly relevant case study of a country's efforts to combat money laundering and the financing of terrorism. In 2008, Mexico underwent its third Mutual Evaluation, and was rated Partially Compliant or Non-Compliant with 25 Recommendations, or put in another way, $51 \%$ of the Recommendations (Chart 5). Of particular concern was Mexico's performance with respect to the Core and Key Recommendations, where the country was rated Partially Compliant or Non-Compliant with nine of 
the sixteen Recommendations. For Mexico, five Core Recommendations were rated Partially Compliant, among them: R.1, R.5, R.13, SR.II and SR.IV, while no Core Recommendations were rated Non-Compliant. Notably, Mexico was identified as having strategic deficiencies in national approaches to the criminaliza-

Chart 5. Compliance Results of Mexico's 2008 Mutual Evaluation

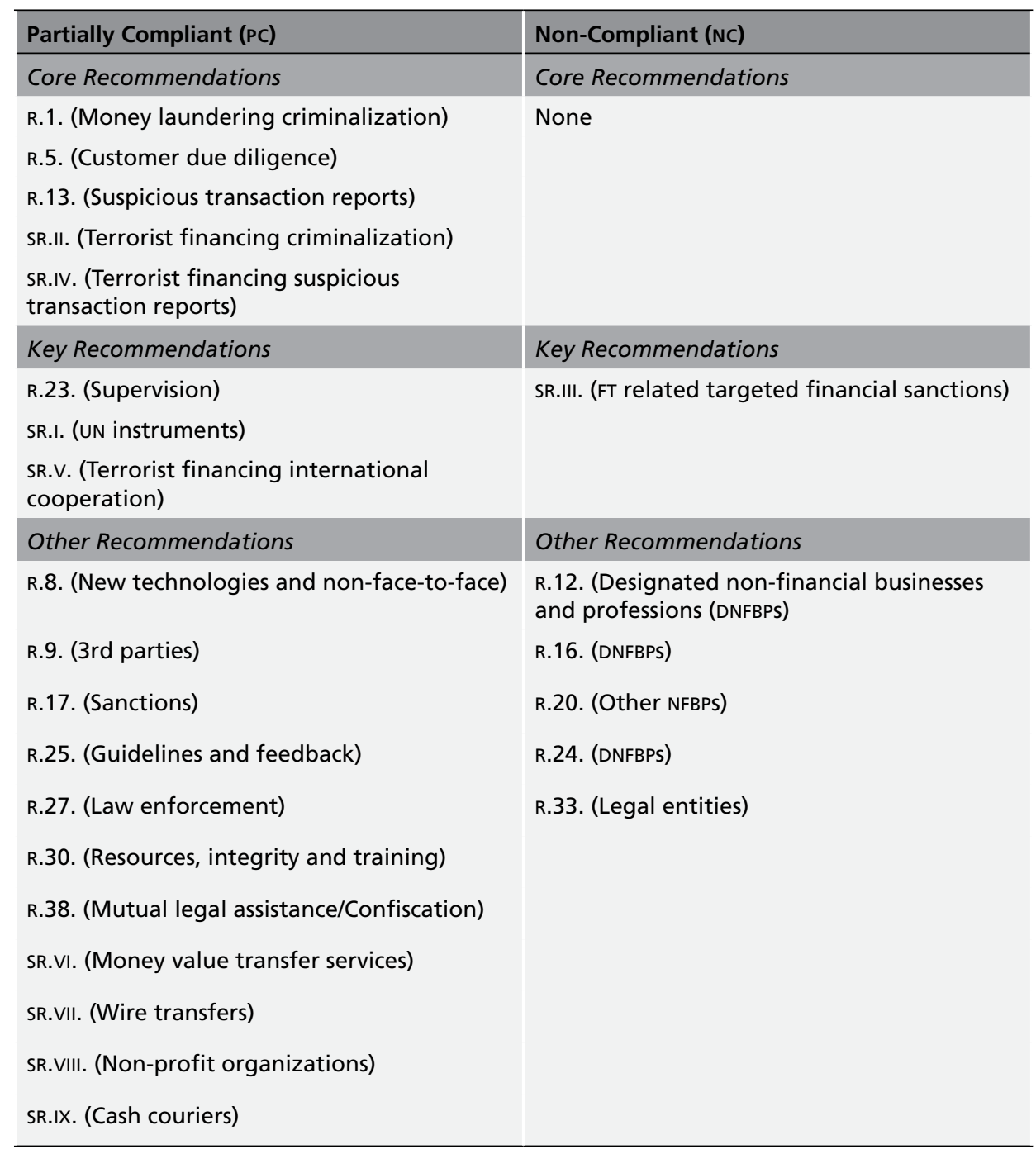

Source: Authors' elaboration based on Financial Action Task Force, Financial Action Task Force of South America and International Monetary Fund (2008). 
tion of money laundering and in practices and regulations, with respect to "know-your-client" customer due diligence principles. As for the Key Recommendations, three were rated Partially Compliant: R.23, SR.I and SR.V, while one was rated Non-Compliant (SR.III, which refers to targeted financial sanctions related to the financing of terrorism). Given these important deficits in Mexico's strategy against money laundering and the financing of terrorism, the FATF Plenary decided in October 2008, that the country should be placed under the regular follow-up procedure, with periodic monitoring reports to be produced by national authorities outlining recent reforms and efforts to address the identified shortcoming in compliance.

Since the results of the 2008 Mutual Evaluation, Mexico has focused on building a comprehensive legal and institutional anti-money laundering and counter-terrorist financing framework. The country has issued or amended several laws and regulations aimed at criminalizing money laundering and the financing of terrorism. Efforts have also been made to improve the prevention of money laundering in the country, through enhanced coordination among national authorities, including law enforcement and judicial officials, as well as with international expert groups and international organizations. The regulatory framework for financial institutions was reformed in line with the $(40+9)$ Recommendations and integrated all the necessary financial supervisory and customer due diligence requirements. In addition, all designated non-financial businesses and professions (DNFBPS) and other risky businesses and professions were incorporated by law into the anti-money laundering and counter-terrorism financing regime. Efforts to combat terrorist financing were also strengthened through the establishment of an asset freezing regime for known or suspected terrorists. Coupled with programs to enhance the judicial process and expedite investigations, prosecutions and convictions, Mexico has adopted an integrated approach in order to protect the long-term stability of the financial system.

As Chart 6 illustrates, Mexico enacted a multi-dimensional national plan to overcome shortcomings in its anti-money laundering and counter-terrorist financing strategy. The national strategy rests on four pillars: 1) information and organization; 2) enhancing the regulatory framework; 3) risk-based supervision and effective banking procedures; and 4) transparency and accountability, which combined serve to enhance national efforts to comply with the FATF Recommendations. Concrete lines of action for various institutional partners, as well as the banking sector have also been identified to public-private cooperation efforts. 


\section{Chart 6. Summary of the National Strategy to Combat Money Laundering and the Financing of Terrorism}

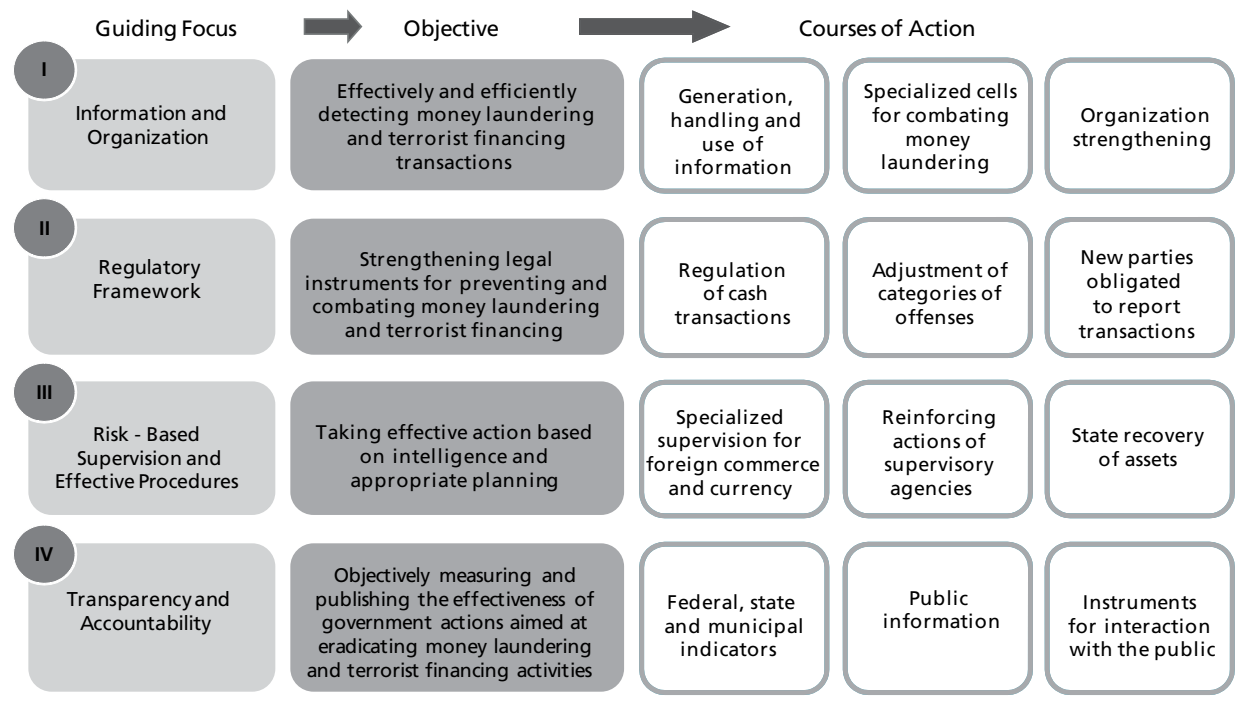

Source: Financial Action Task Force (2012b).

Mexico's first follow-up report to the FATF was issued in October 2010, with the second and third issued in October 2012, and 2013, respectively. The Fourth Follow-up Report, issued in February 2013, illustrated concrete progress in some areas of compliance, but the country was deemed to have shown insufficient progress with regard to some Key Recommendations. At this phase, Mexico entered into a process of Targeted Enhanced Follow-up. Subsequent Follow-up Reports were issued in June 2013 (Fifth Follow-up Report) and October 2013 (Sixth Follow-up Report). In February 2014, Mexico submitted its $7^{\text {th }}$ Follow-up Report to the FATF, as well as its application for removal from the Follow-Up procedure, having identified sufficient progress in addressing the gaps in national compliance, particularly with respect to the Core and Key Recommendations that had been rated Partially Compliant in the third Round Mutual Evaluation (Chart 7).

As this chart illustrates, Mexico has managed to make strides in addressing the shortcomings of national anti-money laundering and counter-terrorist financing programs. All Core and Key Recommendations are now rated Largely Compliant, and the country has shown progress in meeting FATF standards with respect to other Recommendations. One of Mexico's major successes in compliance is its improved performance with respect to Recommendation 1, focusing 


\section{Chart 7. Mexico: 7th Follow-Up Compliance Report with FATF Regulations and Progress Achieved since the Third Round Mutual Evaluation}

\begin{tabular}{|c|c|}
\hline $\begin{array}{l}\text { Core Recommendations Rated Partially } \\
\text { Compliant (PC) }\end{array}$ & Analysis in the $7^{\text {th }}$ Follow-up Report \\
\hline R.1. (Money laundering criminalization) & Progress made, now Largely Compliant (LC) \\
\hline R.5. (Customer due diligence) & Progress made, now LC \\
\hline R.13. (Suspicious transaction reports) & Progress made, now LC \\
\hline SR.II. (Terrorist financing criminalization) & Progress made, now LC \\
\hline $\begin{array}{l}\text { SR.IV (Terrorist financing suspicious transaction } \\
\text { reports) }\end{array}$ & Progress made, now LC \\
\hline $\begin{array}{l}\text { Key Recommendations Rated Non-Compliant } \\
\text { (NC) }\end{array}$ & Analysis in the 7th Follow-up Report \\
\hline SR.III. (FT related targeted financial sanctions) & Progress made, now LC \\
\hline Key Recommendations Rated PC & Analysis in the 7th Follow-up Report \\
\hline R.23. (Supervision) & Progress made, now LC \\
\hline SR.I. (UN instruments) & Progress made, now LC \\
\hline $\begin{array}{l}\text { SR.v. (Terrorist financing international } \\
\text { cooperation) }\end{array}$ & Progress made, now LC \\
\hline Other Recommendations Rated NC & Analysis in the 7th Follow-up Report \\
\hline $\begin{array}{l}\text { R.12. (Designated non-financial businesses } \\
\text { and professions (DNFBPS) }\end{array}$ & Progress made \\
\hline R.16. (DNFBPS) & Progress made \\
\hline R.20. (Other NFBPS) & Progress made \\
\hline R.24. (DNFBPS) & Progress made \\
\hline Other Recommendations Rated PC & Analysis in the 7th Follow-up Report \\
\hline R.8. (New technologies and non-face-to-face) & Progress made \\
\hline R.9. (3rd parties) & Progress made \\
\hline R.17. (Sanctions) & Progress made \\
\hline R.25. (Guidelines and feedback) & Progress made \\
\hline R.27. (Law enforcement) & Progress made \\
\hline R.30. (Resources, integrity and training) & Progress made \\
\hline R.33. (Legal entities) & Progress made \\
\hline R.38. (Mutual legal assistance/Confiscation) & Progress made \\
\hline SR.VI. (Money value transfer services) & Progress made \\
\hline SR.VII. (Wire transfers) & Progress made \\
\hline SR.VIII. (Non-profit organizations) & Progress made \\
\hline SR.IX. (Cash couriers) & Progress made \\
\hline
\end{tabular}


on the criminalization of money laundering. The Federal Criminal Code was amended to address technical shortcomings in the definition and operation of money laundering. In addition, long-term measures were enacted to raise the effectiveness and efficiency of the national criminal system. The country has recently focused on pursuing the prosecution of high-profile money laundering cases, thus raising the effectiveness of the new legislation.

As Chart 8 illustrates, the amount of money seized in recent years in money laundering cases in Mexico has increased rapidly, both in terms of national currency seizures and those in foreign dollar transactions. From 2009 to 2013, monetary seizures in Mexican pesos increased 231\%, while seizures in us dollars increased by more than $600 \%$ as a result of heightened efforts to monitor, detect and capture flows of illicit money.

Chart 8. Amounts Seized in Money Laundering Cases, 2009-2013

\begin{tabular}{|l|r|r|r|r|r|}
\hline & \multicolumn{1}{|c|}{2009} & \multicolumn{1}{|c|}{2010} & \multicolumn{1}{c|}{2011} & \multicolumn{1}{c|}{2012} & \multicolumn{1}{c|}{2013} \\
\hline $\begin{array}{l}\text { Amount of Mexican } \\
\text { pesos seized (in MXN) }\end{array}$ & 247337523 & 97824599 & 179986165 & 354210379 & 820412363 \\
\hline In USD a & 18918998 & 5187945 & 13765874 & 27093768 & 62753842 \\
\hline $\begin{array}{l}\text { Amount in US dollars } \\
\text { seized (in USD) }\end{array}$ & 1192548 & 522044 & 368343 & 39448 & 8450770 \\
\hline
\end{tabular}

a The conversion to USD for all amounts was made with the official exchange rate of 13 January 2014.

Source: Financial Action Task Force (2014b).

While the trend in monetary seizures has increased on average over the last five years, the largest gains have been realized since 2012. As Graph 1 indicates, in terms of both us dollars and Mexican pesos seized, the levels dropped significantly following the 2009 financial crisis. However, in 2013, detection of illicit flows of both currencies increased dramatically. It is expected that due to heightened national efforts to monitor transactions, and increased cooperation among both national and international entities, the amounts of illicit funds seized by Mexican authorities could continue to increase in coming years. The country has adopted an enhanced risk-based approach, which is aligned with the National Strategy to Combat Money Laundering and the Financing of Terrorism, and will be utilized to supervise the financial system and address emerging threats. 


\section{Graph 1. Significant Increases in Monetary Seizures through Money} Laundering Cases, 2009-2013

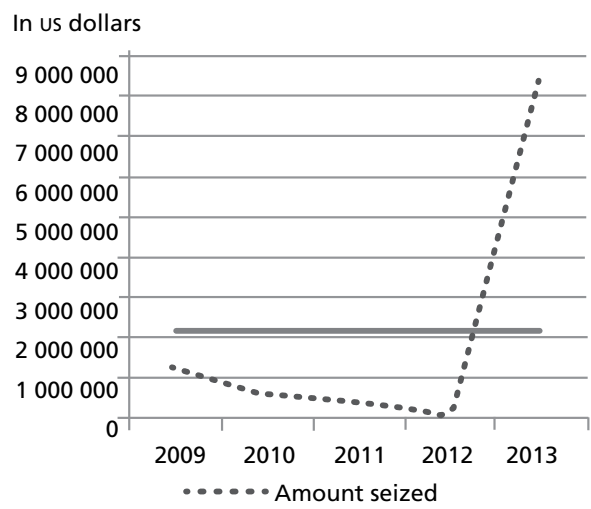

In Mexican pesos

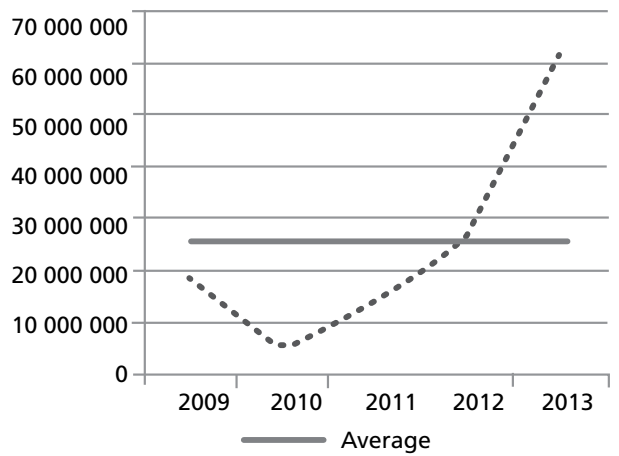

Source: Financial Action Task Force (2014b).

At the Federal level, the number of prosecutions for money laundering cases have also increased, indicating the country's commitment to investigation, and the improved coordination of activities throughout the banking and judicial system. This also reflects increased cooperation with law enforcement agencies and FIUs. Despite the sustained increase in the prosecution rate in Mexico over the last eight years, the conviction rate overall has tapered (Chart 9). From 2006 to 2013, in just over seven years, the number of prosecutions increased by $133 \%$, though the conviction rate dropped from nearly $60 \%$ to less than $20 \%$ over this same time period.

Chart 9. Mexico: Number of Prosecutions, Convictions and Acquittals Related to Money Laundering Cases, 2006-2013

\begin{tabular}{l|l|l|l|l|l|l|l|l|} 
& 2006 & 2007 & 2008 & 2009 & 2010 & 2011 & 2012 & 2013 \\
\hline Prosecutions & 36 & 45 & 61 & 45 & 70 & 108 & 128 & $84^{\text {a }}$ \\
Convictions & 21 & 18 & 29 & 21 & 27 & 33 & 8 & 15 \\
Acquittals & 6 & 8 & 8 & 4 & 5 & 5 & 4 & 5 \\
\hline Conviction Rate & $58.3 \%$ & $40.0 \%$ & $47.5 \%$ & $46.7 \%$ & $38.6 \%$ & $30.6 \%$ & $6.3 \%$ & $17.9 \%$
\end{tabular}

${ }^{\text {a }}$ Mexican Authorities report that in 2013 the FIU made 84 requests for money laundering prosecutions directed to the Federal Prosecutor. In addition, they explained that the Federal Prosecutor could have initiated other money laundering prosecutions. However, they highlight that at the time, with regard to 2013 data, they do not have the information for those potential additional cases.

Source: Financial Action Task Force (2014b). 
In summary, since the 2008 Mutual Evaluation, Mexico has made some notable progress in national efforts to combat money laundering and the financing of terrorism. Following the successful review of its $7^{\text {th }}$ Follow-up Report in February 2014, Mexico was removed from the formal Follow-up procedure by the FATF, reflecting the country's improved performance with respect to Key and Core Recommendations. However, despite this progress, Mexico still has ongoing work in preventing money laundering and the financing of terrorism. A key factor is the country's ability to demonstrate continued compliance and cooperation with the existing Recommendations in future evaluations. In addition, some non-Core and Key Recommendations still need to be addressed for the country to come into full compliance with the full battery of FATF Recommendations. Emerging national and international security threats, as well as the sheer magnitude and complexity of the financial structure in Mexico may weigh on the country's future compliance. Worrisomely, with the erosion of the rule of law in some Mexican states, corruption remains a serious threat to the operations of FIUs, and undermines the effectiveness of the judicial system. An overarching limitation in compliance, as well as in the prosecution and conviction of money laundering and terrorist financing violations, is the weak fiscal capacity of the State. This fiscal precariousness is exacerbated by the extremely low level of tax collection in Mexico, in part due to rampant tax evasion and elusion, as well as deficiencies in the judicial system that have led to few convictions and incarcerations for tax fraud.

\section{Conclusions}

The paper has reviewed the current status of the struggle against money laundering and the financing of terrorism in Latin America and the Caribbean, with special reference to the case of Mexico. It showed that there have been significant advances in the majority of countries in the region in establishing appropriate policies and legislation in the fight against these financial sector security risks. However, it identified major challenges or obstacles that question the continued and effective application of FATF Recommendations, as well as countries' ability to cope with emerging international threats.

Another result of this work is to stress the need for special attention to provide technical support to countries in Latin America and the Caribbean that, according to the Mutual Evaluations conducted, have not yet achieved compliance with more than $50 \%$ of the $(40+9)$ FATF Recommendations. Important concern rises for countries that have low levels of compliance with Key Recommendations, particu- 
larly those who do not comply with Recommendations 5 and 23, relating to due diligence requirements for customer identification, and the absence of laws and regulations that seek to prevent people linked to money laundering or the financing of terrorism from being able to exercise control over or become owners of financial institutions. Coordinated action is required by the international community in order to strengthen these countries' capacity to identify and prosecute criminal activities, including tax evasion and corruption, as well as to comply with international norms aimed at promoting international financial stability and security.

This article also identified new and emerging threats to the financial sector and, more broadly, to macroeconomic security that require the design and implementation of international regulatory standards, particularly with regard to technological advances. Proper systems for monitoring and evaluation will help individual jurisdictions to identify and manage emerging risks. Close transparent cooperation with other jurisdictions and supportive international organizations, including specialist groups and public-private partnerships, can help take a global approach to combating emerging financial crimes, as well as the financing of terrorism and weapons of mass destruction. The same technological innovations that enable the emergence of new risks also provide the international community with tools to combat money laundering and terrorist financing. Technology -based intelligence monitoring, advanced data analytics, and ever-modernizing capacities to share information and analysis in real time with international counterparts, including with law enforcement and judicial agencies, can help to stem the flow of these threats, and strengthen the security of the international financial system, especially because "know your client" policies must include a concrete form of data verification, and follow up monitoring to be effective.

For the case of Mexico, and looking ahead, its next Mutual Evaluation will be conducted in 2018, a year of Presidential elections. The country will be required to demonstrate continued compliance with the previous Recommendations, as well as compliance with the amended set of 2012 FATF Recommendations. The country will also face a stricter set of penalties in the case of non-compliance, with the possibility of inclusion in the FATF's lists of high-risk and non-cooperative jurisdictions. This, by the way, will also apply to Panama, that despite the country's efforts to be removed from the gray list of non-compliant countries, will have to strengthen its continued effort to guarantee the effectiveness of the recently approved legislation. This took a dramatic turn recently in the light of the world leak of the so called Panama Papers revealing once more the country's role as a tax haven. 
44 ECONOMÍA: TEORÍA Y PRÁCTICA • Nueva Época, número 44, enero-junio 2016

\section{AnNeX \\ Chart A1. Latin America and the Caribbean: Compliance with FATF $(40+9)$ Recommendations, 3rd. Round of Mutual Evaluations (continued)}

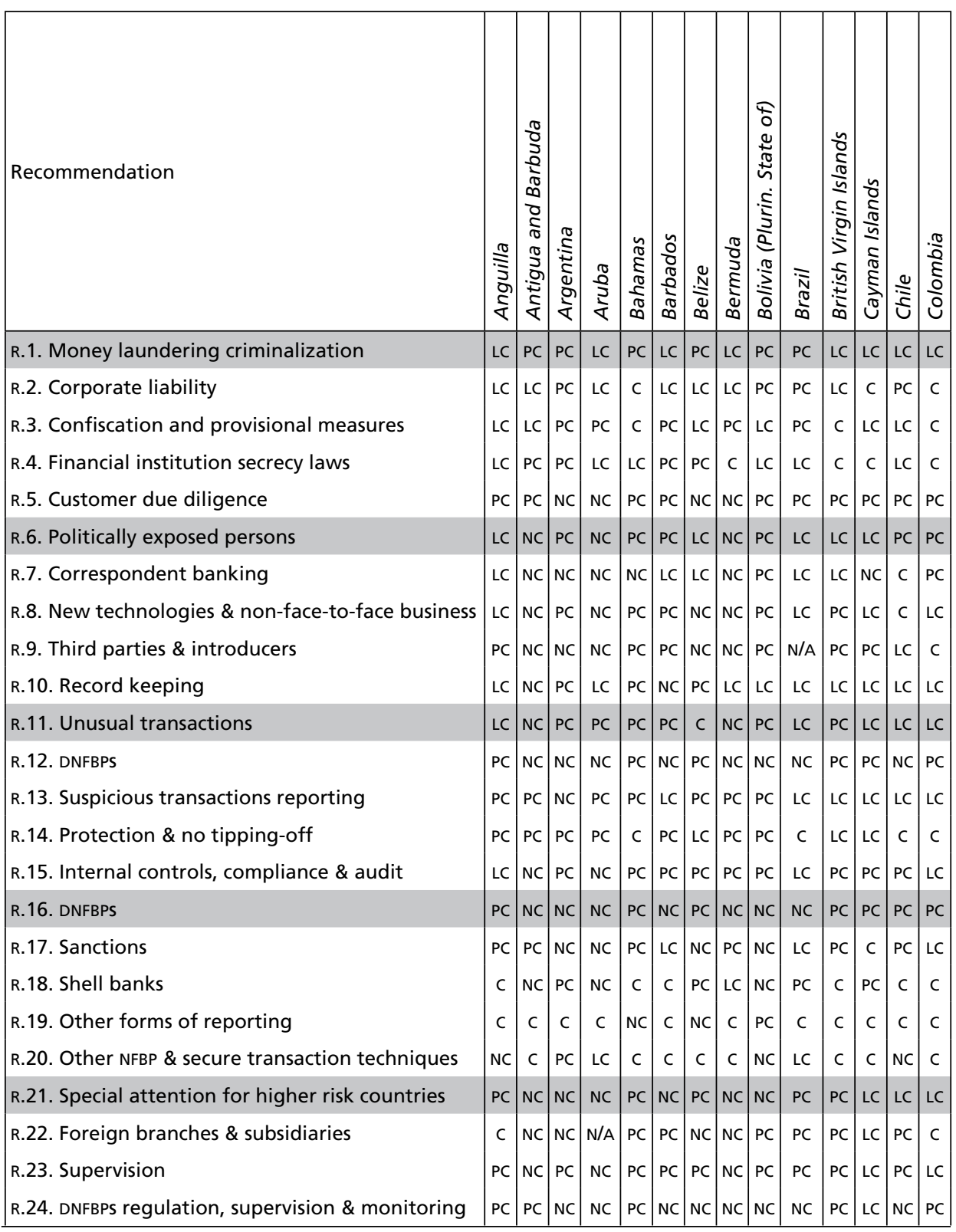




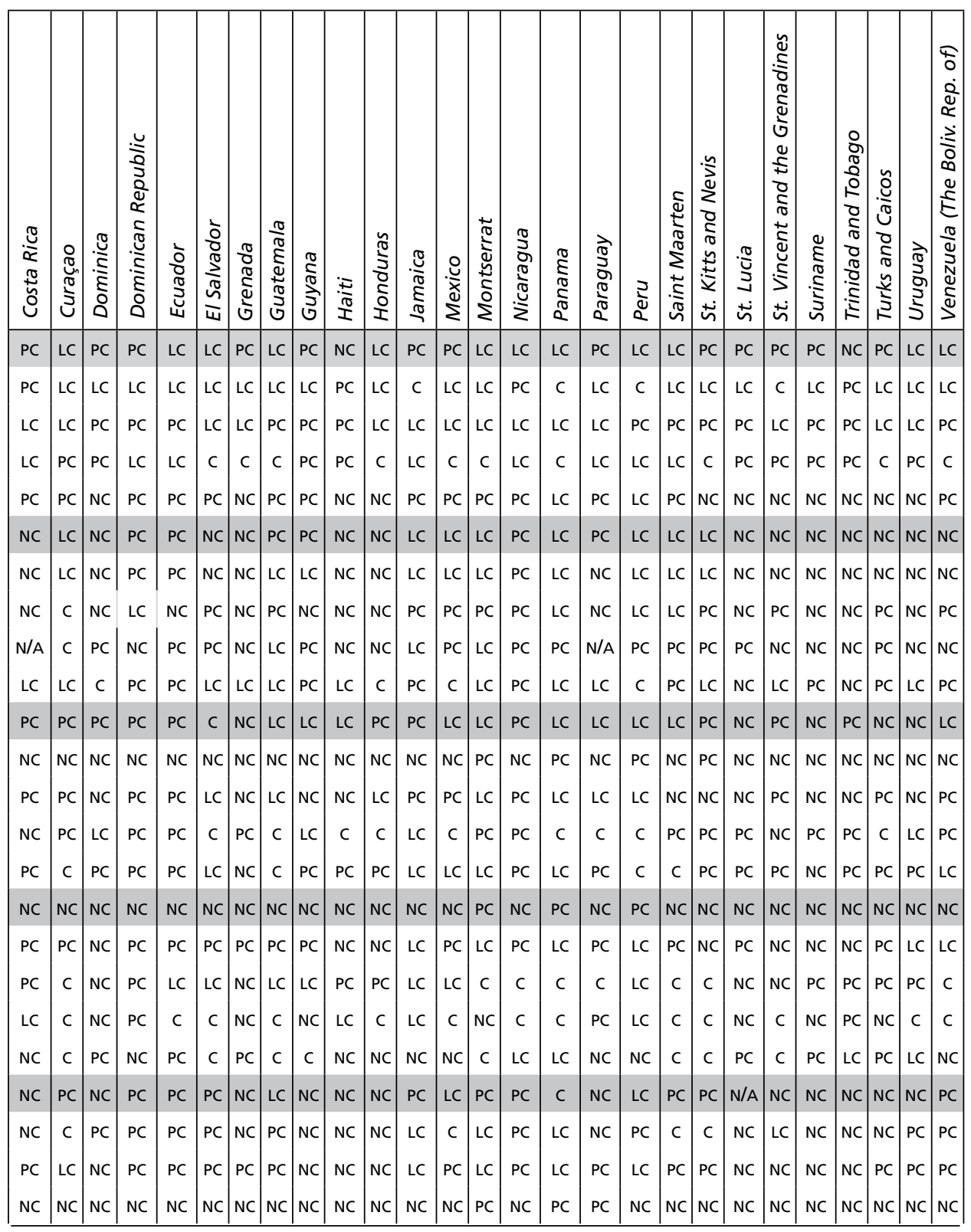


Chart A1. Latin America and the Caribbean: Compliance with FATF $(40+9)$ Recommendations, 3rd. Round of Mutual Evaluations (concludes)

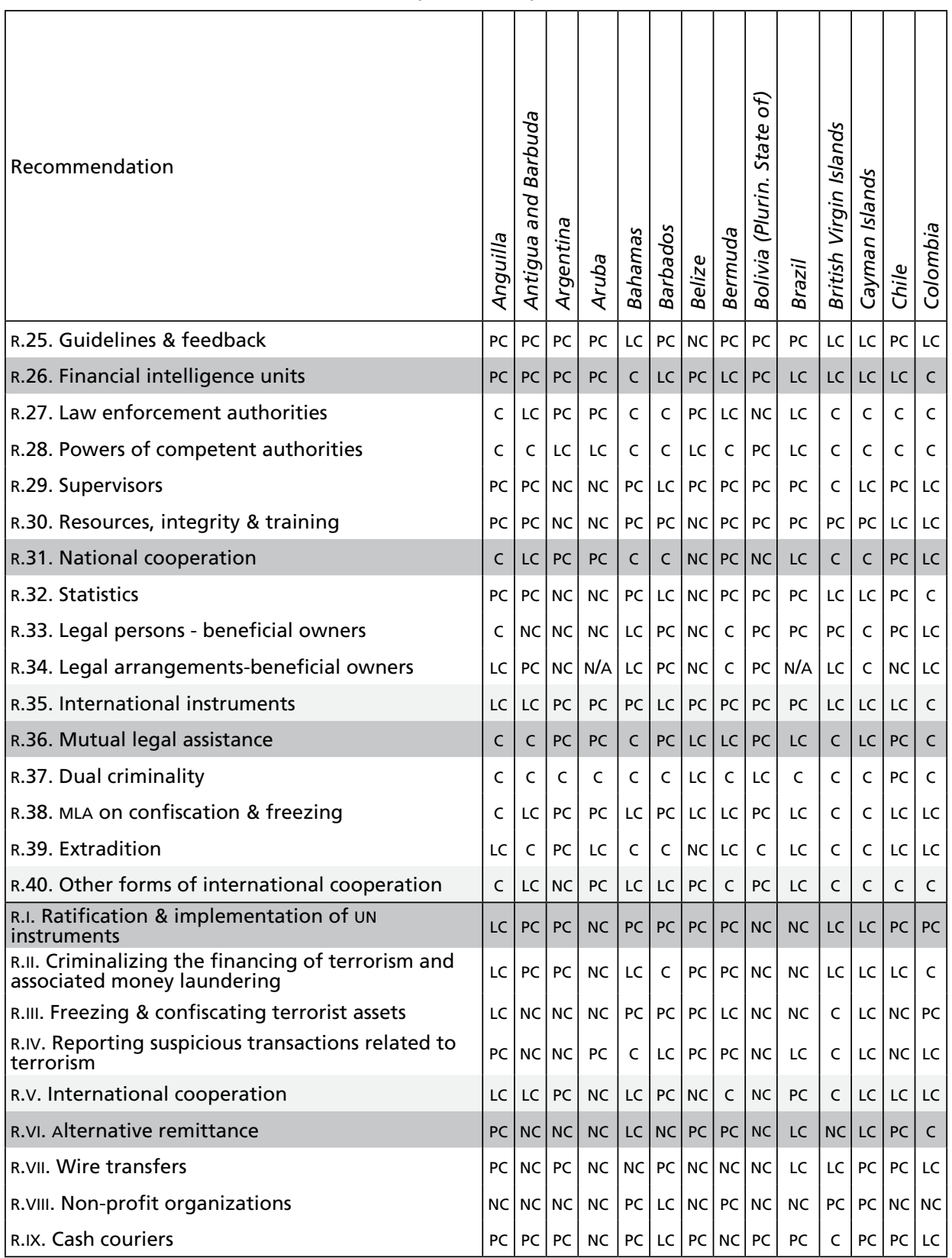

Source: Data compiled from Financial Action Task Force (n.d.), Caribbean Financial Action 


\begin{tabular}{|c|c|c|c|c|c|c|c|c|c|c|c|c|c|c|c|c|c|c|c|c|c|c|c|c|c|c|}
\hline 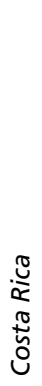 & 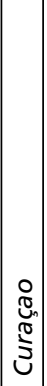 & 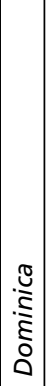 & 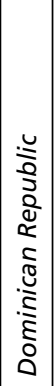 & 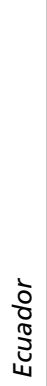 & 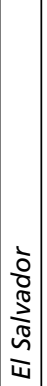 & 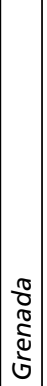 & 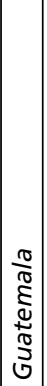 & 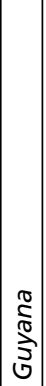 & $\frac{i}{\frac{\pi}{I}}$ & 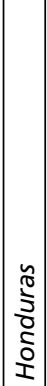 & 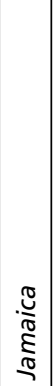 & 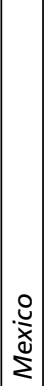 & 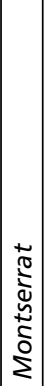 & 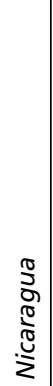 & $\frac{\pi}{\delta} \underset{\sigma}{\sigma}$ & $\begin{array}{l}\vec{\sigma} \\
\frac{\partial}{0} \\
\frac{0}{\sqrt{2}} \\
2\end{array}$ & হ & 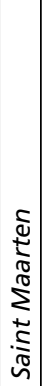 & 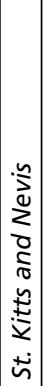 & 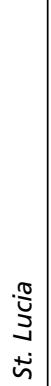 & 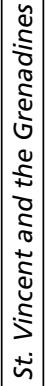 & 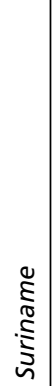 & $\begin{array}{l}0 \\
8 \\
0 \\
0 \\
0 \\
0 \\
0 \\
0 \\
0 \\
0 \\
0 \\
0 \\
: \vdots \\
: \vdots \\
15\end{array}$ & 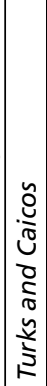 & 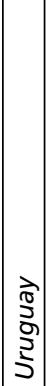 & 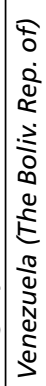 \\
\hline PC & PC & $\mathrm{NC}$ & PC & PC & $\mathrm{NC}$ & $P C$ & LC & $\mathrm{NC}$ & $\mathrm{NC}$ & $\mathrm{NC}$ & PC & PC & PC & PC & PC & $\mathrm{NC}$ & PC & $P C$ & PC & $\mathrm{NC}$ & LC & $\mathrm{PC}$ & $\mathrm{NC}$ & $N C$ & $\mathrm{NC}$ & LC \\
\hline LC & PC & PC & PC & PC & $P C$ & LC & LC & NC & PC & PC & LC & LC & PC & NC & LC & LC & LC & NC & $P C$ & PC & LC & PC & NC & PC & PC & PC \\
\hline LC & LC & PC & LC & PC & C & LC & PC & NC & PC & LC & LC & PC & LC & PC & C & PC & LC & $P C$ & NC & NC & PC & PC & LC & $C$ & C & PC \\
\hline C & LC & PC & PC & LC & C & LC & C & PC & PC & C & LC & LC & LC & PC & C & LC & C & C & LC & LC & C & C & C & $C$ & C & C \\
\hline PC & LC & PC & PC & PC & $P C$ & LC & LC & PC & PC & PC & LC & C & LC & PC & LC & LC & LC & LC & $P C$ & $\mathrm{PC}$ & PC & $\mathrm{NC}$ & NC & PC & LC & LC \\
\hline PC & PC & $\mathrm{NC}$ & PC & PC & $\mathrm{NC}$ & PC & $P C$ & NC & NC & $\mathrm{NC}$ & LC & PC & PC & PC & LC & PC & LC & $P C$ & $P C$ & NC & PC & PC & PC & $\mathrm{NC}$ & $\mathrm{PC}$ & NC \\
\hline LC & PC & $P C$ & LC & LC & PC & PC & PC & NC & PC & NC & LC & LC & PC & PC & PC & ${ }^{\circ} \mathrm{C}$ & C & $\mathrm{PC}$ & $P C$ & NC & LC & LC & PC & PC & PC & LC \\
\hline $\mathrm{NC}$ & PC & NC & NC & LC & $\mathrm{NC}$ & $P C$ & PC & $\mathrm{NC}$ & $\mathrm{NC}$ & PC & LC & LC & PC & PC & LC & PC & PC & $P C$ & $P C$ & $\mathrm{NC}$ & LC & $\mathrm{NC}$ & PC & PC & $\mathrm{NC}$ & NC \\
\hline NC & PC & PC & PC & PC & $P C$ & NC & NC & PC & NC & $\mathrm{NC}$ & LC & NC & PC & NC & NC & PC & C & NC & LC & PC & PC & $\mathrm{NC}$ & PC & PC & NC & NC \\
\hline NC & LC & $\mathrm{NC}$ & $\mathrm{NC}$ & PC & LC & NC & LC & $N C$ & $\mathrm{~N} / \mathrm{A}$ & $\mathrm{NC}$ & C & LC & LC & N/A & LC & LC & C & LC & LC & NC & NC & $\mathrm{N} / \mathrm{A}$ & $\mathrm{NC}$ & PC & LC & PC \\
\hline PC & $P C$ & $P C$ & PC & LC & $C$ & $P C$ & C & PC & $\mathrm{NC}$ & PC & PC & LC & PC & LC & LC & PC & PC & $P C$ & PC & NC & LC & PC & $\mathrm{NC}$ & PC & LC & C \\
\hline PC & LC & LC & PC & $\mathrm{L}$ & LC & C & LC & NC & c & PC & LC & LC & LC & $\mathrm{L}$ & 0 & LC & LC & PC & C & $\mathrm{PC}$ & LC & C & LC & PC & LC & LC \\
\hline LC & LC & C & PC & LC & C & C & C & NC & LC & LC & LC & LC & LC & C & LC & LC & C & LC & C & NC & C & PC & LC & C & C & LC \\
\hline PC & C & PC & PC & LC & LC & LC & PC & $\mathrm{NC}$ & $\mathrm{PC}$ & PC & PC & PC & LC & PC & LC & LC & PC & $P C$ & LC & LC & C & PC & LC & PC & LC & PC \\
\hline LC & LC & LC & LC & LC & PC & C & LC & PC & LC & PC & C & LC & LC & C & C & C & C & $P C$ & C & NC & C & LC & LC & $C$ & C & LC \\
\hline LC & LC & LC & LC & PC & LC & LC & LC & PC & NC & PC & PC & C & LC & PC & C & LC & C & PC & PC & PC & C & PC & PC & PC & $\mathrm{NC}$ & C \\
\hline NC & $\mathrm{PC}$ & PC & $C$ & PC & 8 & $\mathrm{PC}$ & PC & $\mathrm{PC}$ & C & PC & LC & PC & LC & PC & LC & $c$ & PC & PC & PC & NC & NC & NC & NC & PC & $\mathrm{PC}$ & PC \\
\hline $\mathrm{NC}$ & PC & $P C$ & $\mathrm{NC}$ & $\mathrm{P}$ & C & $\mathrm{NC}$ & LC & PC & $\mathrm{NC}$ & PC & LC & PC & PC & $\mathrm{L}$ & $\mathrm{LC}$ & $\mathrm{NC}$ & LC & $\mathrm{NC}$ & $P C$ & NC & LC & $\mathrm{NC}$ & $\mathrm{NC}$ & PC & PC & PC \\
\hline NC & PC & PC & NC & NC & LC & NC & $P C$ & $\mathrm{NC}$ & $\mathrm{NC}$ & $\mathrm{NC}$ & LC & NC & PC & $\mathrm{NC}$ & PC & NC & $\mathrm{NC}$ & $P C$ & $P C$ & NC & $\mathrm{NC}$ & $\mathrm{NC}$ & $\mathrm{NC}$ & LC & PC & NC \\
\hline NC & PC & $\mathrm{NC}$ & NC & PC & PC & $\mathrm{NC}$ & LC & PC & $\mathrm{NC}$ & C & PC & PC & LC & $P C$ & LC & $\mathrm{NC}$ & LC & $\mathrm{NC}$ & $\mathrm{NC}$ & $\mathrm{NC}$ & $\mathrm{NC}$ & $\mathrm{NC}$ & $\mathrm{NC}$ & PC & $\mathrm{NC}$ & PC \\
\hline NC & LC & PC & NC & LC & PC & $P C$ & LC & NC & $\mathrm{NC}$ & PC & LC & PC & PC & PC & LC & PC & PC & $P C$ & $P C$ & $\mathrm{NC}$ & LC & $\mathrm{NC}$ & $\mathrm{NC}$ & LC & PC & LC \\
\hline PC & PC & $N$ & LC & $P$ & $\mathrm{NC}$ & $N$ & LC & $c$ & NC & $\mathrm{NC}$ & LC & PC & PC & $\mathrm{NC}$ & LC & C & LC & $\mathrm{NC}$ & $P C$ & NC & PC & $\mathrm{NC}$ & $\mathrm{NC}$ & PC & NC & PC \\
\hline PC & LC & NC & PC & $P C$ & $P C$ & NC & LC & NC & $\mathrm{nc}$ & $\mathrm{NC}$ & PC & PC & LC & $P C$ & C & NC & LC & $P C$ & PC & $\mathrm{PC}$ & NC & $\mathrm{NC}$ & $\mathrm{NC}$ & NC & NC & NC \\
\hline PC & $\mathrm{NC}$ & NC & NC & NC & PC & $\mathrm{NC}$ & PC & $\mathrm{NC}$ & $\mathrm{NC}$ & $\mathrm{NC}$ & NC & PC & $\mathrm{PC}$ & PC & PC & $\mathrm{NC}$ & LC & $\mathrm{NC}$ & PC & NC & LC & $\mathrm{NC}$ & $\mathrm{NC}$ & $\mathrm{NC}$ & PC & NC \\
\hline $\mathrm{NC}$ & PC & $P$ & N/A & PC & $\mathrm{PC}$ & NC & PC & 4 & $\mathrm{pc}$ & PC & N/A & PC & NC & PC & PC & $\mathrm{NC}$ & N/A & NC & NC & NC & LC & NC & $\mathrm{NC}$ & NC & $\mathrm{NC}$ & NC \\
\hline
\end{tabular}

Task Force (n.d.) and Financial Action Task Force of South America (n.d.). 


\section{REFERENCES}

African Development Bank (2009). African Development Bank Group Strategy for the Prevention of Money Laundering and Terrorist Financing in Africa. ADB/BD/ WP/2007/70-ADF/BD/WP/2007746, Tunisia: African Development Bank.

Asian Development Bank (2003). Enhancing the Asian Development Bank's Role in Combating Money Laundering and the Financing of Terrorism. Manila: Asian Development Bank.

- (2008). Review of Enhancing the Asian Development Bank's Role in Combating Money Laundering and the Financing of Terrorism. Manila: Asian Development Bank.

Bartlett, Brent L. (2002). The Negative Effects of Money Laundering on Economic Development. Manila: Asian Development Bank.

Caribbean Financial Action Task Force (2008). Regional Typologies. Port of Spain: CFATF.

— (n.d.). 3rd Round Meval Reports. [online] Available at https://www.cfatf-gafic. org/index.php/documents/mutual-evaluation-reports. [Accessed April 19, 2016].

Egmont Group (2016). About Egmont Group. [online] Available at: http::/www.egmontgroup.org. [Accessed April 19, 2016].

Eastern Caribbean Central Bank (1995). Anti-Money Laundering Guidance Notes for Licensed Financial Institutions. [online] Available at http://www.eccb-centralbank.org/PDF/Anti-Money.pdf. [Accessed April 19, 2016].

Financial Action Task Force (2004). FATF 40 Recommendations. October 2003 (incorporating all subsequent amendments until October 2004). [online] Paris: FATF. Available at http://www.fatf-gafi.org/publications/fatfrecommendations/documents/the40recommendationspublishedoctober2004.html. [Accessed April 19, 2016].

- (2006). The Misuse of Corporate Vehicles, Including Trust and Company Service Providers. Paris: FATF/OECD.

(2008). Mandate 2004-2012. Paris: FATF/OECD.

(2012a). Annual Report 2011-2012. Paris: FATF/OECD.

(2012b). Interim Follow-up Report, Mutual Evaluation of Mexico. Paris: FaTf/ OECD.

(2012c). The FATF Recommendations 2012: International Standards on Combating Money Laundering and the Financing of Terrorism \& Proliferation. [online] Paris: FatF/OECD. Available at http://www.fatf-gafi.org/publications/fatfre- 
commendations/documents/fatf-recommendations.html. [Accessed April 19, 2016].

(2013a). Annual Report 2012-2013. Paris: FATF/OECD.

(2013b). The Methodology for Assessing Compliance with the FATF Recommendations and the Effectiveness of AML/CFT Systems. Paris: FATF/OECD.

(2014a). FATF Public Stament - 27 June 2014 High-risk and non-cooperative jurisdictions. [on line] Paris: FATF. Available at http://www.fatf-gafi.org/media/ FATF/documents/statements/Public-Statement-27-June-2014.pdf. [Accessed April 19, 2016].

(2014b). Mutual Evaluation of Mexico: 7th Follow-up Report. Paris: FATF/OECD. (n.d.). Topic: Mutual Evaluations. [online] Available at http://www.fatf-gafi. $\mathrm{org} /$ publications/mutualevaluations $/ ? \mathrm{hf}=10 \& \mathrm{~b}=0 \& \mathrm{~s}=\mathrm{desc} \% 28 \mathrm{fatf}$ releasedate\%29. [Accessed April 19, 2016].

Financial Action Task Force, Financial Action Task Force of South America and International Monetary Fund (2008). Mutual Evaluation of Mexico. Paris: FATF.

Financial Action Task Force of South America (2006). Regional Typologies. Buenos Aires: GAFISUD.

- (2008). Regional Typologies. Buenos Aires: GAFISUD.

- (n.d.). Evaluaciones mutuas e informes de seguimiento. [online] Available at http://www.gafilat.org/content/biblioteca/. [Accessed April 21, 2016].

International Monetary Fund and World Bank (2001). Enhancing Contributions To Combating Money Laundering: Policy Paper. [online] Available at https://www.imf. org/external/np/ml/2001/eng/042601.PDF. [Accessed April 21, 2016].

John Walker Consulting Services (1995). Estimates of the Extent of Money Laundering in and through Australia. Prepared for the Australian Transaction Reports and Analysis Centre.

United Nations (2006). The United Nations Global Counter-Terrorism Strategy. A/RES/60/ 288. [online] New York: United Nations. Available at https://documents-dds-ny. un.org/doc/UNDOC/GEN/N05/504/88/PDF/N0550488.pdf?OpenElement. [Accessed April 19, 2016].

United Nations Security Council (2004). Resolution 1540. S/RES/1540. [online] New York: United Nations. Available at http://www.un.org/en/ga/search/view_doc. asp?symbol=S/RES/1540\%20(2004). Accessed April 19, 2016].

(2006a). Resolution 1673. S/RES/1673. [online] New York: United Nations. Available at http://www.un.org/en/ga/search/view_doc.asp?symbol=S/RES/ 1673(2006). [Accessed April 19, 2016].

_ (2006b). Resolution 1695. S/RES/1695. [online] New York: United Nations. 
Available at http://www.un.org/en/ga/search/view_doc.asp?symbol=S/RES/ 1695\%282006\%29. [Accessed April 19, 2016].

(2006 c). Resolution 1718. S/RES/1718. [online] New York: United Nations. Available at http://www.un.org/en/ga/search/view_doc.asp?symbol=S/RES/ 1718\%282006\%29. [Accessed April 19, 2016].

(2006d). Resolution 1737. S/RES/1737. [online] New York: United Nations. Available at https://www.iaea.org/sites/default/files/unsc_res1737-2006.pdf. [Accessed April 19, 2016].

_ (2007). Resolution 1747. s/RES/1747 (2007). [online] New York: United Nations. Available at https://www.iaea.org/sites/default/files/unsc_res1747-2007. pdf. [Accessed April 19, 2016].

_ (2008a). Resolution 1803. S/RES/1803. [online] New York: United Nations. Available at https://www.iaea.org/sites/default/files/unsc_res1803-2008.pdf. [Accessed April 19, 2016].

(2008b). Resolution 1810. S/RES/1810. [online] New York: United Nations. Available at http://www.un.org/en/ga/search/view_doc.asp?symbol=S/RES/ 1810\%20(2008). [Accessed April 19, 2016].

(2014). Resolution 2178. S/RES/2178. [online] New York: United Nations. Available at http://www.un.org/en/sc/ctc/docs/2015/SCR\%202178_2014_EN.pdf. [Accessed April 19, 2016].

United States Department of State, Bureau for International Narcotics and Law Enforcement Affairs (2008). International Narcotics Control Strategy Report. Volume II. Money Laundering and Financial Crimes, Washington, DC.

United States Department of Treasury (2007). National Money Laundering Strategy. Washington, DC: n.e.

United States Department of the Treasury, Financial Crimes Enforcement Network (2016). USA PATRIOT Act. [online] Available at https://www.fincen.gov/statutes regs/patriot/. [Accessed April 19, 2016].

United States Department of Treasury, Money Laundering Threat Assessment Working Group. (2005). Us Money Laundering Threat Assessment. Washington, DC: n.e. Wolfsberg Group (2016). Wolfsberg Anti-Money Laundering Principles. [on line] Available at http://www.wolfsberg-principles.com. [Accessed April 19, 2016]. 